\title{
Covenant Violations, Loan Contracting, and Default Risk of Bank Borrowers
}

Felix Freudenberg $_{\dagger} \quad$ Björn Imbierowicz ${ }^{\ddagger}$ Anthony Saunders* ${ }^{*}$ Sascha Steffen ${ }^{\S}$

November 18, 2011

Preliminary and Incomplete

$\dagger$ Goethe University Frankfurt. Email: felix.freudenberg@hof.uni-frankfurt.de. Tel: +496979833733

† Goethe University Frankfurt. Email: imbierowicz@finance.uni-frankfurt.de. Tel: +49 6979833729

* Stern School of Business, New York University. Email: asaunder@stern.nyu.edu. Tel: +1 2129980711

$\S$ University of Mannheim. Email: steffen@bank.bwl.uni-mannheim.de. Tel: +49621 1811531 


\title{
Covenant Violations, Loan Contracting, and Default Risk of Bank Borrowers
}

\begin{abstract}
Are borrowers rewarded for repaying their loans? This paper investigates the consequences of covenant violations on subsequent loans to the same borrower using a hand-collected sample of US syndicated loans during the 1996 to 2010 period. We find that covenant violations have substantial negative effects for borrowers in subsequent loans. Our results show that the loan spread increases by 22 basis points in the loan following the violation. We also find that the new contract includes more financial covenants which are also more restrictive. Switching banks after a violation does not reduce these effects and even leads to a further increase in loan spreads. We also provide empirical evidence that borrowers who have violated covenants in the previous contract are significantly more likely to violate covenants again in the next loan. Moreover, they violate earlier compared to borrowers who have not violated covenants before. Most importantly, these borrowers also exhibit a substantially higher likelihood to default, particularly in the first 100 days after a violation. Our results suggest that there is an important role for covenants in monitoring borrowers and that covenant violations provide an early warning signal for a severe deterioration of borrower credit quality.
\end{abstract}

Keywords: Covenant Violation, Financial Default, Syndicated Loans. 


\section{Introduction}

Are borrowers rewarded for repaying their loans? We analyze this question for a sample of U.S. firms who are recurring borrowers in loan markets and focus on the contract design of newly issued loans. More specifically, we analyze violations of covenants and their effects on subsequent loans. Covenants are an integral part of private credit agreements. Empirical studies, however, have only recently started to examine covenants particularly with respect to contract renegotiations, corporate investments and debt structure. We contribute to this literature studying the implications of covenant violations for new loans from the same borrowers. How are these contracts designed? Do borrowers have to pay higher spreads after violations? Are lenders tougher on borrowers increasing the number of covenants and making contracts stricter? How is borrower performance affected? Are borrowers repeatedly violating covenants? And, are borrowers also more likely to default if they have previously violated covenants?

At the core of our analysis is a novel and hand collected dataset of loans and covenants which we construct from original loan contracts from the borrowers' SEC filings. Our sample comprises 3,183 loans over the 1996 to 2010 period after applying a large number of filters and after matching these contracts to LPC Dealscan and borrowers to the merged CRSP/Compustat database. We collect more than 80 different covenant types and definitions from these contracts and classify them into 17 groups of financial covenants. We also know step-up and step-down provisions for each covenant. We use all information available to us from these contracts to calculate covenant violations on a quarterly basis.

We start analyzing loan spreads and the number of covenants for loans of recurring borrowers. We find that borrowers are rewarded for not violating covenants paying significantly lower spreads. Lenders also reduce the number of covenants in subsequent loan contracts. Violations, on the other hand, increase loan spreads as well as the number of covenants. Interestingly, we find that negative effects attenuate if borrowers repeatedly borrow. Using Bradley and Roberts (2004) covenant index, we also find that contracts become stricter after violations. Moreover, we find that borrowers who violated covenants in the previous contract are about $30 \%$ more likely to violate again in the current loan, and they also violate sooner than other borrowers. Larger firms as well as investment grade rated firms are less likely to violate while highly leveraged firms as well as non-investment grade rated firms are more likely to violate covenants. 
Overall, we find that lenders substantially increase the number and intensity of covenants after violations which is consistent with the interpretation that covenant violations are used as an early warning signal for deteriorating borrower creditworthiness and that lenders increase monitoring efforts making loan contracts stricter.

Starting in 1987, we have a complete history of borrower and lender pairs in this market, and we use this information to classify borrowers into whether or not they switch lenders after violations. Roberts and Sufi (2009) find that borrowers hardly switch lenders after covenant violations. We study the effect of switching on loan contract terms and find that switching (not conditioning on previous violations) increases loan spreads but has hardly any effect on the number or intensity of covenants. Neither do we find an effect on the propensity to violate. However, borrowers who violate are doing this earlier than borrowers who have not switched lenders.

We do not find that there is an additional mark-up on loan spreads for borrowers who switch after violations. Segregating our sample into opaque and transparent firms (based on borrower age, size and rating status) does not reveal a spread increase for those who have switched and violated either. Interestingly, we find that borrowers who switch after violations are less likely to violate repeatedly compared to those who do not switch. A possible interpretation is that new lenders invest more time and effort in screening and monitoring these borrowers.

In the last part of the paper, we ask given that covenant violations provide an early warning signal with respect to borrower health, whether this is also reflected in higher default rates of borrowers who violate. We augment our dataset with Chapter 11 filings from the UCLALoPucki bankruptcy database to examine this question using three different approaches: First, we investigate the impact of a covenant violation in the previous loan contract on the probability to default. Second, we construct a covenant violation dummy equal to 1 if the firm violates a covenant between 1,080 to 180 days before the default date. Third, instead of focusing on the last contract before default, we use the entire universe of loan contracts of our sample borrowers assess the effects of covenant violations in any of the borrower's previous loans (not necessarily the last one). This allows us to assess whether violations in the past still have some predictive power. Overall, we find that covenant violations substantially increase the likelihood of future default. However, the likelihood of default decreases substantially the more time has passed after the last covenant violation. The conditional probability of default (PD) is $36 \%$ on the first day after the covenant violation and it continues to be substantially higher compared to the 
unconditional PD for the first 100 days after covenant violation. Taken together, our results suggest that there is an important role for covenants in monitoring borrowers and that covenant violations provide an early warning signal for a severe deterioration of borrower credit quality.

Our paper adds to the literature studying the effects of covenants and covenant violations. Nini et al. (2010) find a decline in acquisitions and capital expenditures after a violation. Furthermore, borrowers decrease their leverage and CEO turnover increases. Chava and Roberts (2008) discover a sharp decline in investment spending, which is particularly pronounced if information problems are more severe. Roberts and Sufi (2009) and Demiroglu and James (2010) show that tighter covenants decrease investment spending and net debt issuances. The importance of covenant violations is further emphasized by Dyreng (2009). He highlights that borrowers engage in earnings management in order to prevent covenant violations. None of these papers however, studies the role of covenant violations as early warning indicator and monitoring instrument. Moreover, we study violations not only in the cross-section of borrowers but also in the time series using a history of hand-collected loans for borrowers who recurrently borrow in the loan market.

The paper proceeds as follows. The next section describes how we construct the dataset and provides some descriptive statistics. Section 3 shows the results relating contract violations to the design of subsequent loans and the performance of borrowers which respect to future violations and corporate default. Section 4 concludes.

\section{Data and Descriptive Statistics}

\subsection{Data}

To investigate the effect of covenant violations on subsequent loans, we construct a new data set collecting original loan contracts directly from the Security and Exchange Commission (SEC) filings of public firms using EDGAR (Electronic Data-Gathering, Analysis and Retrieval). Material loan contracts have to be reported as required by the SEC and can be found as an exhibit to a $10-\mathrm{K}, 10-\mathrm{Q}$ or $8-\mathrm{K}$ report. We start with the set of private credit agreements provided by Greg Nini, David Smith and Amir Sufi who collected these contracts for the 1996 to 2005 period 
and extend this set of contracts for 5 more years until the end of $2010 .{ }^{1}$ Their sample includes 3,720 contracts amended in our data set with 1,276 additional loans.

We start with the universe of 4,996 private credit agreements for the 1996 to 2010 period available from Dealscan. We exclude all observations where we cannot identify a contract in EDGAR as well as loans specified as amendments in Dealscan or in the loan contract following Roberts (2010). In other words, all contracts are new loans. $96 \%$ of these loans can be matched to the contracts from EDGAR. Although Dealscan already provides some information on negative and financial covenants which is also more complete particularly starting in 2000 , we still find that several covenants are missing from our contracts. Furthermore, the definition of seemingly similar covenants differs substantially between contracts and is aggregated in Dealscan without further information. Additionally, only one threshold for financial covenants is recorded in the database, but thresholds frequently change. ${ }^{2}$ We therefore manually build a novel set of covenants in private credit agreements collecting all covenants from 3,813 contracts. We do not use any text-search program to avoid possible misspecification of the algorithm.

Private loan agreements typically include both negative and financial covenants. ${ }^{3}$ Negative covenants prevent the borrower from certain actions such as excessive investments, distribution of too high dividends, sale of assets, changes in company control, entering sale-andlease-back transactions, or a change in business activities. Financial covenants are often termed "performance hurdles" (Roberts and Sufi, 2008) or "trip wires" (Dichev and Skinner, 2001) due to their ability to shift control rights. Examples of financial covenants are accounting-based amounts and ratios which can be found in the reporting data of the company (e.g. Taylor and Sansone, 2007; Nini et al., 2008). There exist maintenance and incurrence covenants. The former imply that the borrower has to meet certain criteria on a regular basis where the latter refer to a predetermined event, such as the issuance of new debt or the acquisition of another company.

We record the threshold for each quarter from origination to final maturity of each loan because it changes several times in many loans. These step-down or step-up provisions cannot be found in Dealscan. Furthermore, we find about 80 different definitions of covenants and classify

\footnotetext{
${ }^{1}$ Nini, Smith and Sufi (2009) and Roberts and Sufi (2009).

${ }^{2}$ Appendix I shows an example of a financial covenant section in a loan contract.

${ }^{3}$ We do not include affirmative covenants such as punctual payment of interest and principal, delivery of financial statements, property and equipment maintenance, compliance to accounting standards, or paying insurance and taxes, as these are often not observable following, for example, Bradley and Roberts (2004) and Demiroglu and James (2010).
} 
them into 17 main covenant types. ${ }^{4}$ We describe them in Table I. However, we use the definitions of all 80 covenants to identify covenant violations using the corresponding information from the company's financial statements.

To construct our data set, we merge the contracts from EDGAR with several other data sources. We obtain loan contract information from Dealscan including loan spread (AISD), maturity, loan amounts and lender identity. To identify repeated borrowing from the same lender as well as switching between lenders, we construct the merger history for each lender in Dealscan using information obtained from the FDIC and the National Information Center (NIC). Using Robert's Dealscan-Compustat Linking Database (Chava et a.. (2008)), we collect quarterly financial statement information from Compustat and merge it to each loan contract. We exclude all loans for which this information is not available. Finally, we obtain borrower default information via the Chapter 11 filings in the UCLA-LoPucki bankruptcy research database. All variables are described in Table I. The final dataset includes 3,813 loans with 5,411 loan facilities.

\section{[Table I]}

\subsection{Covenants and covenant violations}

Using the covenants collected from the SEC filings, we construct several proxies as to the strictness of contracts and covenant violations. We define the Number of Financial Covenants as the sum over the indicator variables representing the 17 main covenant types shown in Table I. A contract with more covenants is more restrictive compared to a contract with fewer covenants.

Our Covenant Intensity Index reflects the tightness of the covenants following Bradley and Roberts (2004). It includes not only financial but also negative covenants. The index ranges from zero to six with high values indicating intense covenants. It is constructed summing the indicator variables for dividend restriction, equity sweep, asset sweep, debt sweep, securitization, and a binary variable that is one if the contract includes two or more financial covenants.

\footnotetext{
${ }^{4}$ The substantially larger number of covenants can be explained by the variety of definitions of the respective variables. Consider for example a debt to capitalization covenant. Debt can be senior, long term or defined as the total value. Capitalization can refer to net worth plus equity or tangible net worth plus equity.
} 
The borrower has to comply with most financial covenants on a quarterly basis (Roberts and Sufi, 2008). A covenant is violated if the corresponding accounting value is above or below its respective threshold.

Days to Covenant Violation is measured as the difference between inception of the contract until the end of the quarter during which a financial covenant is violated for the first time.

\subsection{Descriptive Statistics}

\subsubsection{Loan Contracts and Borrower Characteristics}

The final data set consists of 5,411 facilities (3,813 loans) over the 1996 to 2010 period. Table II provides detailed summary statistics on loan and borrower characteristics. All data are measured in real terms with 2000 as the base year.

\section{[Table II]}

The average loan facility is $\$ 298$ million with an All-In-Spread-Drawn (AISD) of 183 basis points (bps) and 2.55 financial covenants. The covenant intensity index is derived following Bradley and Roberts (2004) and loans contain, on average, 4.55 out of 6 possible restrictions. $55 \%$ of the loans are violated and these violations occur on average 14 months (427 days) after the loan origination date. Furthermore, we find an average borrower default rate of $2.5 \%$. Borrowers switch banks in $35.1 \%$ of all cases and violate a financial covenant in more than half $(57.2 \%)$ of all of their previous loan contracts.

The average borrower size is $\$ 3,291$ million with a profitability of $16 \%$, a current ratio of 1.84 , a leverage ratio of 0.32 , an interest coverage ratio of 15.44 , and a market-to-book ratio of 1.68. More than one half of the loans are rated and $24.1 \%$ are classified as investment and $34.5 \%$ as non-investment grade.

\subsubsection{Covenant Violations}

To get a better understanding of how spreads and covenant restrictions evolve as borrowers repeatedly borrow in the loan market, we graphically explore average loan spreads and number of covenants in loan contracts as a function of previous covenant violations when 
borrowers obtain a loan for the second, third, and fourth time. Figure 1 shows how loan spreads develop for a borrower who obtains loans from the same lender. The number of observations is provided in parentheses.

[Figure 1]

A first time borrower pays on average 193 bps above LIBOR which decreases to $77 \mathrm{bps}$ in the fourth contract conditional on never having violated a covenant. Borrowers also become less opaque as they frequently borrow in the loan market. At the same time, always violating a covenant in the first three loans increases loan spreads to 213bps in the fourth loan. A violation in the first loan increases loan spreads to 210bps, not violating a covenant in the second loan reduces spreads to $129 \mathrm{bps}$ in the third loan. Interestingly, a borrower who violates a covenant in the second but not the first loan pays, on average, 150bps if she borrows for the third time. In other words, the effect of violations on spreads dissipates over time. Overall, Figure 1 shows that covenant violations results in higher spreads for borrowers in subsequent loans.

A similar pattern is observable with respect to the number of financial covenants in new loan contracts.

[Figure 2]

Figure 2 shows how the average number of the financial covenants develops over time as borrowers frequently return to the loan market. Not violating covenants reduces the number of covenants in subsequent loans, whereas the number of covenants increases following a covenant violation in the previous contract. Again, we observe that the effect of covenants violations is more pronounced in the contract following the violation.

In Table III, we segregate the entire sample based on whether or not the borrower violated a covenant in the previous contract.

[Table III]

Columns A and B show mean and median characteristics for borrowers who did not (did) violate a covenant in the previous contract. The last column reports the parametric t-statistic 
(nonparametric z-statistic) of the difference in means (medians) test. Table III shows that the differences between both groups substantial. On average, borrowers have to pay a higher spread of $98 \mathrm{bps}$, accept 0.6 more financial covenants which are in addition significantly more restrictive. On the other hand, borrowers who violate a covenant in the previous loan contract again violate contract terms in $70 \%$ of all loans, within a shorter time period from to the contract start date and furthermore are significantly more likely to default.

Table III also shows that borrowers who violated covenants are more likely to switch lenders in the next loan. If lenders reward borrowers for switching, having violated covenants might have fewer consequences as to lower spreads or less strict covenants. We investigate the effects of switching lenders on loan contract terms especially after having violated a covenant in our multivariate analysis. We also find that loan amounts decrease after a covenant violation. Moreover, the percentage of secured loans almost doubles. Borrowers who violate covenants are also smaller, higher leveraged with lower interest coverage and market-to-book ratio and they are also lower rated.

Overall, the univariate results are consistent with the interpretation that covenant violations provide an early warning signal for deteriorating borrower performance and that covenants are used by banks to monitor borrowers.

\subsubsection{Repeated Borrowing}

Table IV tabulates various contract characteristics (spread, covenant measures and defaults) grouped by the number of loans of the same borrower.

[Table IV]

Panel A of Table IV focuses on loans of borrowers from the same lender. That is, we observe how contract characteristics develop over a bank-borrower relationship. Loan spreads are decreasing which is consistent with the literature (for example, Bharath et al. (2011)), we also observe a lower number of covenants and lower default rates as the relationship evolves consistent with the monitoring role of relationship lenders. Interestingly, the covenant intensity is increasing. One possible interpretation is that an increase in covenant intensity associated with 
covenant violations (note that both violation and non-violations are included) is dominating possible positive relationship effects.

Panel B of Table IV shows the results also grouped by the number of loans from the same borrower but not conditional on borrowing from the same lender. In other words, we observe both relationship borrowers as well as firms that switch lenders. Interestingly, we do not find lower loan spreads for borrowers who borrow repeatedly in the loan market. We observe fewer covenants and a lower likelihood to violate covenants. However, covenant intensity is increasing as well as the likelihood to default.

Overall, we find evidence consistent with relationship benefits with regard to lower loan spreads and fewer covenants. Repeated borrowing alone does not reduce loan spreads.

\section{Results}

In this section, we analyze the effect of a covenant violation on contract terms in subsequent loans. In all tests, we control for loan characteristics including maturity (months), a dummy variable when the loan is secured, and the natural logarithm of the facility size. We also include borrower characteristics such as profitability, current ratio, leverage, coverage, market to book ratio, total assets, and borrower credit rating. Furthermore, we account for time (calendar year), industry (one-digit SIC industry classification), loan type, and loan purpose fixed effects as well as clustering of error terms at the firm level and potential heteroscedasticity.

\subsection{Covenant violations and loan contract terms}

To analyze the effect of covenant violations on the design of subsequent loan contracts, we use a regression framework of the following form:

$$
\begin{aligned}
\text { LCT }= & a+b * \text { PreviousCovenantViolation }+c * \text { LoanCharacteristics } \\
& +d * \text { BorrowerCharacteristics }+e * \text { OtherControls }+\varepsilon
\end{aligned}
$$


LCT ('Loan Contract Terms') refers to the different dependent variables. There are: AISD, Number of Covenants, Covenant Intensity, Contract Violation and Days to Contract Violation. The results are reported in Table V.

\section{[Table V]}

Table $\mathrm{V}$ reports five models, one for each dependent variable. It also shows the regression methodology used in each regression. Column 1 of Table $\mathrm{V}$ reports the results of an OLS regression relating AISD to previous covenant violations and other control variables (loan characteristics, borrower characteristics, and rating). We find that previous covenant violations increase loan spreads on subsequent loans by 22 bps which is significant at the $1 \%$ level and economically meaningful. Most of the other control variables are also highly significant and carry the expected signs. For example, larger loans have lower spreads, secured loans and highly leveraged loans carry larger spreads. All variables are defined in Table I. Standard errors are clustered at the borrower level. Columns 2 and 3 of Table V report the results of an ordered logit regression relating the number of covenants and covenant intensity to covenant violations and our control variables. We find that previous violations increase the number of covenants. The coefficient is significant at the $1 \%$ level. Covenant intensity is also increasing, the coefficient, however, is only weakly significant. The number of observations also drops to 848 in Column 3 because we need to rely on data reported by Dealscan in order to calculate the index in a similar fashion as in Bradley and Roberts (2004), Demiroglu and James (2010) and Bharath et al. (2011). Information about asset sweep, equity sweep or secured status is missing in many cases. In Column 4 we analyze the effect of previous covenant violations on the likelihood to violate in the subsequent loan and find a positive effect. Having violated a covenant in the previous contract increases the likelihood to violate by $30 \%$. The control variable are as expected, larger and investment grade rated firms are less likely to violate, whereas firms with higher leverage and larger loan sizes (that is, ceteris paribus more debt and higher interest expense) are more likely to violate. Column 5 then analyzes the time period until a new violation occurs in a subsample of loans to borrowers that all violate at least 1 covenant. We find that previous covenant violations significantly reduce the time until the next violation occurs. 


\subsection{Switching and loan contract terms}

Next, we analyze the effect of switching between banks on contract terms. If lenders reward borrowers for switching, having violated covenants might have fewer consequences as to lower spreads or less strict covenants.

$$
\begin{aligned}
\text { LCT }= & a+b * \text { Switch }+c * \text { LoanCharacteristics }+d * \text { BorrowerCharacteristics } \\
& +e * \text { OtherControls }+\varepsilon
\end{aligned}
$$

We follow Ioannidou and Ongena (2010) and define Switch as an indicator variable equal to 1 when the borrower did not have a lending relationship with the lead arranger in a new contract over at least 1 year. ${ }^{5}$ The various loan contract terms discussed above are our dependent variables in models 1 to 5 . The results are reported in Table VI.

[Table VI]

Column 1 of Table VI reports an increase in loan spreads of 12bps when firms switch banks. On the other hand, the number of financial covenants decreases (Column 2) although the coefficient is only significant at the $10 \%$ level. Switching does not have an effect on the restrictiveness of covenants (Column 3) and does not affect the likelihood to violate covenants in subsequent contracts. However, if borrowers violate, firms that switch violate about 2 months (65 days) earlier compared to other firms.

\subsection{Covenant violations, switching and loan contract terms}

\subsubsection{Switching, covenant violations and loan spreads}

Our earlier results show that covenant violations in the previous loan contract leads to a higher spread in the subsequent loan. Switching banks has a similar effect. We next ask whether

\footnotetext{
${ }^{5}$ This definition implicitly assumes that private information banks learn about borrowers is not durable and dissipates after 1 year. We use other definitions for Switch in robustness tests and find similar results.
} 
borrowers who have violated a covenant switch banks to avoid a markup both in pricing as well as covenant strictness. We estimate the following model:

$$
\begin{aligned}
\text { AISD }=a & +b * \text { PreviousCovenantViolation }+c * \text { Switch } \\
& +d * \text { PreviousCovenantViolation } * \text { Switch }+e * \text { LoanCharacteristics } \\
& +f * \text { BorrowerCharacteristics }+g * \text { OtherControls }+\varepsilon
\end{aligned}
$$

LCT is our dependent variables (ASID, Number of Covenants, Covenant Intensity, Contract Violation, and Days to Contract Violation). The results are reported in Table VII.

\section{[Table VII]}

Columns 1 and 2 repeat our earlier tests for comparison. In Column 3, we include both Switch and Previous Covenant Violation in the same model and add the interaction term in Column 4. Our earlier results still hold, that is both switching as well as having violated covenants in the previous loan increase loan spreads. The interaction term is insignificant. Overall, borrower who switch lenders after violating covenants pay approximately 40 bps higher loan spreads.

Is there a differential effect for opaque borrowers? We use 3 opaqueness proxies to analyze this question. There are: (i) young which is a dummy variable equal to 1 if borrowers are less than 3 years listed on an exchange. (ii) Small is a dummy variable which is 1 if borrower's asset size falls into the $25 \%$ percentile of the distribution of our sample firms, and (iii) Not Rated is a dummy variable equal to 1 if the firm does not have an $\mathrm{S} \& \mathrm{P}$ long-term issuer rating. The results are reported in Columns 5 to 7.

Column 5 shows that opaque (that is young) firms pay larger spreads consistent with prior literature (for example, Bharath et al. (2011) and Saunders and Steffen (2011)). ${ }^{6}$ However, we do not find that opaque firms pay significantly more after switching or after having violated compared to more transparent firms.

\footnotetext{
${ }^{6}$ We may find no significant effect for small borrowers because all firms in our sample are rather large, have their stock traded on an exchange and therefore are subject to the reporting requirements of public firms.
} 


\subsubsection{Switching, covenant violations and number of covenants}

We next analyze the effect of switching after covenant violations on the number of financial covenants (NUMCOV) in the next loan using a similar setup as above.

$$
\begin{aligned}
\text { NUMCOV } & =a+b * \text { PreviousCovenantViolation }+c * \text { Switch } \\
& +d * \text { PreviousCovenantViolation } * \text { Switch }+e * \text { LoanCharacteristics } \\
& +f * \text { BorrowerCharacteristics }+g * \text { OtherControls }+\varepsilon
\end{aligned}
$$

The results are reported in Table VIII.

\section{[Table VIII]}

Columns 1 and 2 repeat our earlier tests for comparison. Columns 3 and 4 of Table VIII show that switch does not have a significant effect on the number of covenants controlling for previous covenant violations. A covenant violation, however, substantially increases the number of covenants in the subsequent loan. Switching after having violated, on the other hand, does not have a significant effect. Interestingly, loans to young firms (Column 5) have fewer covenants after switching, but only if she has not violated a covenant before switching. In that case, we do not find any effect. As in our earlier tests, larger and investment grade rated firms have fewer covenants.

Overall, lenders substantially increase the number of covenants in loans to borrowers that have violated covenants in the previous contract which is consistent with the interpretation that covenant violations are used as an early warning signal for a deterioration of a borrower's creditworthiness and lenders increase monitoring efforts making loan contracts stricter. Switching, however, does not have any effect on the number of covenants. 


\subsubsection{Switching, covenant violations and covenant intensity}

If lenders increase their monitoring effort, is this also reflected in the intensity of the covenants (COVINT)?

$$
\begin{aligned}
\text { COVINT } & =a+b * \text { PreviousCovenantViolation }+c * \text { Switch } \\
& +d * \text { PreviousCovenantViolation } * \text { Switch }+e * \text { LoanCharacteristics } \\
& +f * \text { BorrowerCharacteristics }+g * \text { OtherControls }+\varepsilon
\end{aligned}
$$

The results are reported in Table IX.

[Table IX]

Again, Columns 1 and 2 repeat our earlier tests for comparison. Consistent with higher monitoring effort of lenders, we find that covenant intensity is also increasing in the loan after a borrower has violated covenants. We find that switching lenders does not have an impact on covenant intensity either with or without having violated covenants before. Our opaqueness proxies do not show a differential effect for opaque relative to transparent firms. ${ }^{7}$

Taken together, our tests show that covenant violations in the previous loan contract have substantial effects on the design of subsequent loan contracts. Violations increase borrowing costs, the number of financial covenants, and covenant intensity. Switching banks amplifies the effect on loan spreads but does not have a meaningful effect on covenants in subsequent loans.

\subsection{The Propensity to Violate Covenants}

Are borrowers more likely to violate covenants again after having violated financial covenants in the previous loan contract? Is the effect different for firms that switch after the

\footnotetext{
${ }^{7}$ As we require all six indicator variables to be available for the calculation of the intensity index the total number of observations diminishes substantially compared to the whole sample. We can therefore not estimate the triple interaction term for young firms which already contain only a few observations as mentioned above.
} 
violation? And, is there a differential effect for opaque firms? We analyze these questions using a similar regression model as above.

$$
\begin{aligned}
\operatorname{Pr}(\text { VIOL }) & =a+b * \text { PreviousCovenantViolation }+c * \text { Switch } \\
& +d * \text { PreviousCovenantViolation } * \text { Switch }+e * \text { LoanCharacteristics } \\
& +f * \text { BorrowerCharacteristics }+g * \text { OtherControls }+\varepsilon
\end{aligned}
$$

$\operatorname{Pr}(\mathrm{VIOL})$ is an indicator that is 1 if the borrower violates at least 1 covenant in the new loan. The results are reported in Table X.

\section{[Table X]}

Borrowers who have violated covenants in the previous contract are $30 \%-35 \%$ more likely to violate covenants in the subsequent loan contract. This effect is significant at the $1 \%$ level. We also find an effect for borrowers who switch lenders after a violation. The interaction term indicates a $21 \%$ lower likelihood to violate a covenant again. A possible interpretation is that new lenders invest more effort into due diligence and monitoring. Larger firms and investment grade rated firms are less likely to violate. We find weak evidence that opaque borrowers are more likely to violate again (after already having violated in the previous contract).

Conditional on violating covenants in $2^{\text {nd }}, 3^{\text {rd }}, \ldots$ loan, when are covenants violated? More precisely, we focus on the time period between contract initiation date and covenant violation (DAYS).

$$
\begin{aligned}
\text { DAYS }= & a+b * \text { PreviousCovenantViolation }+c * \text { Switch } \\
& +d * \text { PreviousCovenantViolation } * \text { Switch }+e * \text { LoanCharacteristics } \\
& +f * \text { BorrowerCharacteristics }+g * \text { OtherControls }+\varepsilon
\end{aligned}
$$


Table XI reports the results using a hazard rate $\operatorname{model}^{8}$. Note that a positive coefficient implies an earlier occurrence of covenant violations.

[Table XI]

We find only week evidence that borrowers who switch violate covenants earlier compared to firms who do not switch lenders. Borrowers who have violated covenants in the previous contract, however, also violate significantly earlier compare to other firms. This is consistent with covenant violations being an early warning signal of elevated borrower risk because these borrowers violate covenants in the subsequent loan contract more often and within a shorter time period.

\subsection{Covenant Violations and Default Rates}

If covenant violations provide an early warning signal about borrower health, is this also reflected in higher default rates? To examine this, we expand our data set with Chapter 11 filings obtained from the UCLA-LoPucki bankruptcy research database which ultimately collects its information from court files or SEC filings. We know the exact default date of each borrower and measure the predictive power of covenant violations via three different approaches.

First, we follow our earlier analyses and investigate the impact of a covenant violation in the previous loan contract on the probability to default before the subsequent loan contract matures.

Second, we construct a covenant violation dummy equal to 1 if the firm violates a covenant between 1,080 to 180 days before the default date. The contracts with covenant violations from 180 days prior to default until the default date are excluded due to a potentially increasing endogeneity of this variable when the default date approaches.

Third, instead of focusing on the last contract before default, we use the entire universe of loan contracts of our sample borrowers and construct a variable Violation in Past Contracts which is equal to 1 if the borrower violated covenants in any of her previous loans (not necessarily the last one). Even though the quality of violations as early warning signal should be highest the

\footnotetext{
${ }^{8}$ All results are confirmed in OLS regressions.
} 
closer the violation is to the default date, even violations in the past might have some predictive power. The results are reported in Table XII.

\section{[Table XII]}

Columns 1 to 4 follow our empirical setup described earlier. We find that covenant violations in the previous contract increase the likelihood to default. Borrowers who switch (with our without having violated covenants) are not more likely to default.

Column 5 (Model 2) shows that covenant violations 1,080 to 180 days before the default date also substantially increase the probability of default. As mentioned above we exclude the last half year due to potential endogeneity. ${ }^{9}$

Finally, model 3 shows that covenant violations in general contain information about borrower default probability. Is this information durable? We construct a new variable Ln(Days since Past Covenant Violation) which is the natural logarithm of the days between the last covenant violation and the last observable loan (before default) and interact it with the covenant violation variable. The coefficient of the interaction term is negative and significant at the $1 \%$ level. That is, having violated financial covenants in the past increases a borrower's default probability substantially, however, the default likelihood is significantly lower the more time passes since the covenant violation date.

To analyze this further, we use keep everything fixed at the mean value of each variable and predict borrower default probability only varying the number of days from the most recent violation date until the start date of the current loan contract (after which the borrower either defaults or not) using Column 9. Figure 3 plots the predicted default probability against the days since the most recent contract violation.

[Figure 3]

We add a straight line to show the predicted default probability of the average borrower which is $0.61 \%$ and much smaller compared to average default rate of $2.5 \%$ of our full sample.

\footnotetext{
${ }^{9}$ Note that the coefficient increases to 3.124 , significant at the $1 \%$ level, if this time period is included.
} 
There are two reasons for this: First, we use the predicted value which, second and more importantly, is derived on a subsample as we investigate only borrowers with at least two contracts and exclude contracts of all borrowers with no previous covenant violation.

The borrower has a probability of default (PD) of $35.82 \%$ at the first day after a covenant violation. Figure 3 also shows that borrower PD is substantially higher in the period directly following the violation and decreases as a convex function over time. Borrowers exhibit a substantially higher likelihood to default especially in the first 100 days after a violation. Figure 3 also supports our results in model 2 of Table XII because it shows a higher PD also until 3 years after a covenant was violated. The borrower PD takes more than 8 years $(3,012$ days $)$ until it is close to the average level of $0.61 \%$ again. This is consistent with covenant violations being an indicator of elevated borrower risk.

\section{Conclusion}

In this paper, we analyze the effect of covenant violations on the design of loan contracts using a hand-collected data set of covenants in 5,411 loan facilities over the 1996 to 2010 period. Covenants are an important element of loan contracts and can be found in almost every private credit agreement.

Overall, we provide empirical evidence that the violation of loan covenants provides an early warning signal of elevated borrower risk. We find that lenders respond to violations increasing loan spreads and the number of covenants. Furthermore, they increase the intensity of covenants. Borrowers who have already violated covenants are significantly more likely to default and to default earlier after loan origination. Consistently, we find that borrowers are more likely to file for Chapter 11, particularly in the first 100 days after they have violated covenants. 


\section{References}

Berger, A. N. and G. F. Udell (1995) Relationship lending and lines of credit in small firm finance, Journal of Business, 68, 351-382.

Berlin M. and L. Mester (1998) Deposits and Relationship Lending, Review of Financial Studies, 2, 95-133.

Berlin, M. / Mester, L. (1992): Debt covenants and renegotiation, in: Journal of Financial Intermediation, Vol. 2, p. 95 - 133.

Bharath, S. T., S. Dahiya, A. Saunders and A. Srinivasan (2007) So what do I get? The bank's view of lending relationships, Journal of Financial Economics, 85, 368 - 419.

Bharath, S. T., S. Dahiya, A. Saunders and A. Srinivasan (2010) Lending relationships and loan contract terms, Review of Financial Studies, forthcoming.

Bhattacharya, S. and G. Chiesa (1995) Proprietary Information, Financial Intermediation and Research Incentives, Journal of Financial Intermediation, 4, 328-357.

Black / Fischer (1976): The dividend puzzle, in: Journal of Portfolio Management, Vol. 5, p. $5-8$.

Boot, A. (2000) Relationship banking: What do we know?, Journal of Financial Intermediation, 9, 7-25.

Bradley, M. / Roberts M. (2004): The structure and pricing of debt covenants, Unpublished Working Paper (May 13, 2004), Available at SSRN: http://ssrn.com/abstract=466240, accessed September 18, 2009.

Carey, M. / Prowse, S. / Rea, J. / Udell, G. (1993): The economics of the private placement market, Working Paper, Board of Governors of the Federal Reserve. 
Cole, R. A. (1998) The importance of relationships to the availability of credit, Journal of Banking and Finance, 22, 959-977.

Degryse, H. and P. van Cayseele (2000) Relationship lending within a bank-based system: Evidence from European small business data, Journal of Financial Intermediation, 9, 90-109.

Demiroglu, C. / James, C. (2010): The information content of bank loan covenants, Review of Financial Studies, Vol. 23, $3700-3737$.

Denis, D. / Mihov, V. (2003): The choice among bank debt, non-bank private debt, and public debt: evidence from new corporate borrowings, in: Journal of Financial Economics, Vol. 70, p. 3 - 28.

Diamond, D. (1984): Financial intermediation and delegated monitoring, in: Review of Economics Studies, Vol. 51, p. 393 - 414.

Dichev, D. / Skinner, D. (2001): Large-sample evidence on the debt covenant hypothesis, in: Journal of Accounting Research, Vol. 40, Issue 4, p. 1091 - 1123.

Dyreng, S. (2007): The cost of private debt covenant violation, Working Paper, University of North Carolina.

Fama, E. (1985): What's different about banks?, in: Journal of Monetary Economics, Vol. 15 , p. $29-39$.

Fama, E. / Miller, M. (1972): The theory of finance, Holt, Rinehart and Winston, New York.

Gale, D. / Hellwig, M. (1985): Incentive-compatible debt contracts: The one-period problem, in: Review of Economic Studies, Blackwell Publishing, Vol. 52, Issue 4, p. 647 - 63. 
Greenbaum, S. I., G. Kanatas and I. Venezia (1989) Equilibrium loan pricing under the bank-client relationship, Journal of Banking and Finance, 13, 221-235.

Hart, O. / Moore, J. (1998): Default and renegotiation: a dynamic model of debt, in: Quarterly Journal of Economics (1998), Vol.113, p. 1 - 42.

Jensen, M. / Meckling, W. (1976): Theory of the firm: Managerial behavior, agency costs, and ownership structure, in: Journal of Financial Economics, Vol. 3, p. $305-360$.

Kahan, M. / Tuckman, B. (1993): Private vs. public lending: evidence from covenants, Unpublished Working Paper (July 1, 1993), Available at http://repositories.cdlib.org/cgi/viewcontent.cgi?article=1152\&context=anderson/fin, accessed September 22, 2009.

Modigliani, F. / Miller, M. (1958): The cost of capital, corporation finance and the theory of investment, in: The American Economic Review, Vol. 48, p. 261 - 297.

Myers, S. (1977): Determinants of corporate borrowing, in: Journal of Financial Economics, Vol. 5, p. 147 - 175.

Nini, G. / Smith, D. / Sufi, A. (2008): Creditor control rights and firm investment policy, in: Journal of Financial Economics, Vol. 92, p. 400 - 420.

Rajan, R. G. (1992) Insiders and outsiders: The choice between informed and arms length debt, Journal of Finance, 47, 1367-1400.

Petersen, M. / Rajan, R. (1994): The benefits of lending relationships: Evidence from small business data, in: Journal of Finance, Vol. 49, Issue 3, p. 1367 - 1400. 
Ramakrishnan, R. T. S. and A. V. Thakor (1984) Information reliability and a theory of financial intermediation. Review of Economic Studies, 45, 415-432.

Roberts, M. / Sufi, A. (2008): Control rights and capital structure: an empirical investigation, in: Journal of Financial Economics, Vol. 64, p. 1657 - 1695.

Sharpe, S. A. (1990) Asymmetroc information, bank lending and implicit contracts: A stylied model of customer relationships, Journal of Finance, 45, 1069-1087.

Smith, C. / Warner, J. (1979): On financial contracting: an analysis of bond covenants, in: Journal of Financial Economics, Vol. 7, p. 117 - 161.

Taylor, A. / Sansone, A. (2007): The Handbook of Loan Syndications and Trading, McGrawHill, New York.

Townsend, R. (1979): Optimal contracts and competitive markets with costly state verification, in: Journal of Economic Theory, Vol. 21, Issue 2, p. 265 - 293.

Verde, M. (1999): Loan preserve: The value of covenants, FitchIBCA Loan Products Special Report, Available at http://pages.stern.nyu.edu/ igiddy/articles/fitch_loan_ covenants.pdf, accessed August 22, 2009.

Wilson, P. F. (1993) The pricing of loans in a bank-borrower relationship, Working Paper, Indiana University. 


\section{Figure 1}

\section{The Effect of Past Covenant Violations on the All-in-Spread-Drawn}

The figure shows how the average All-in-Spread-Drawn evolves over the number of loans a borrower obtains from the same lender. It is split into whether a covenant was violated in the previous loan (1) or not $(0)$. The number of loan observations is shown in parentheses.

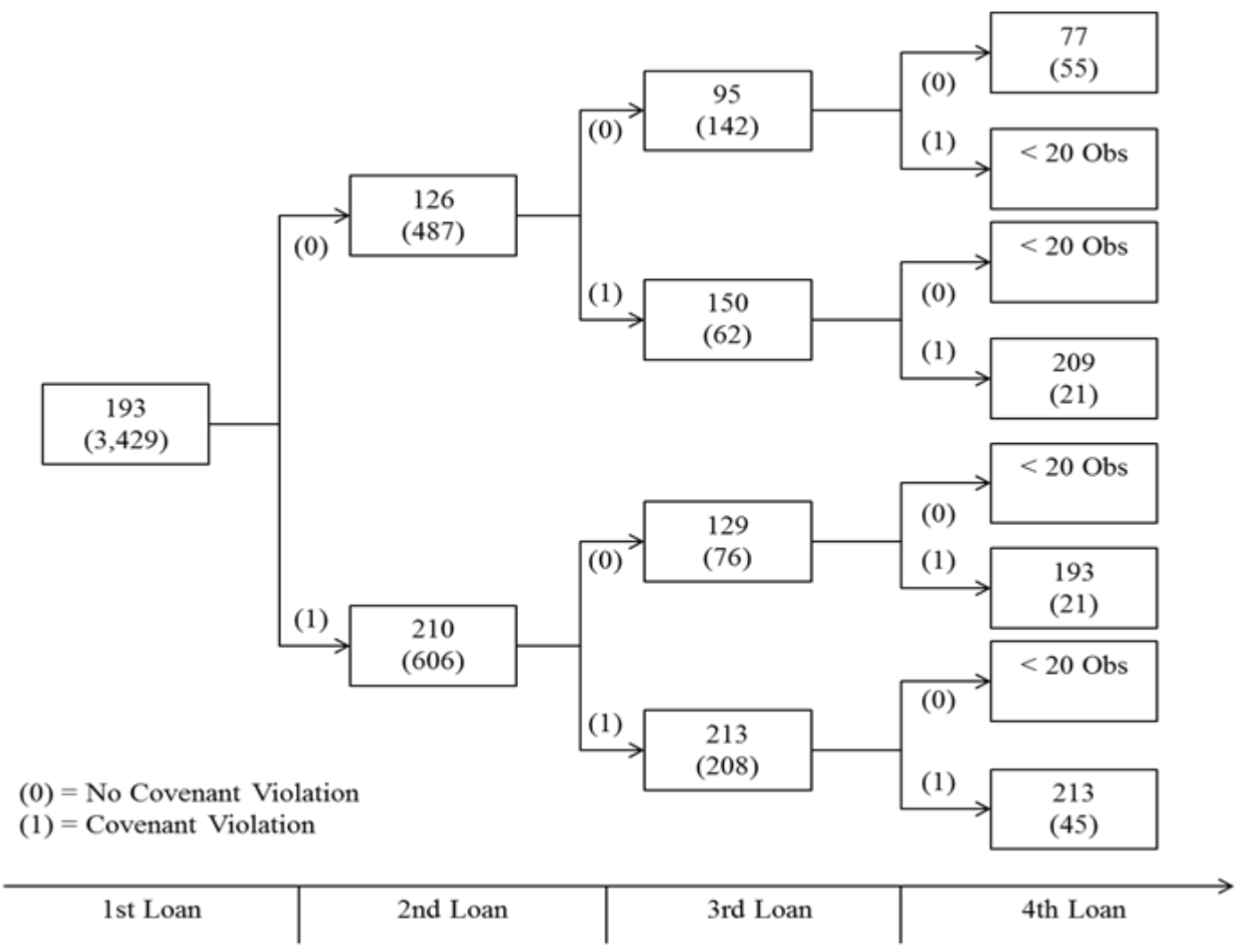




\section{Figure 2}

\section{The Effect of Past Covenant Violations on the Number of Financial Covenants}

The figure shows how the average number of financial covenants evolves over the number of loans a borrower obtains from the same lender. It is split into whether a covenant was violated in the previous loan (1) or not (0). The number of loan observations is shown in parentheses.

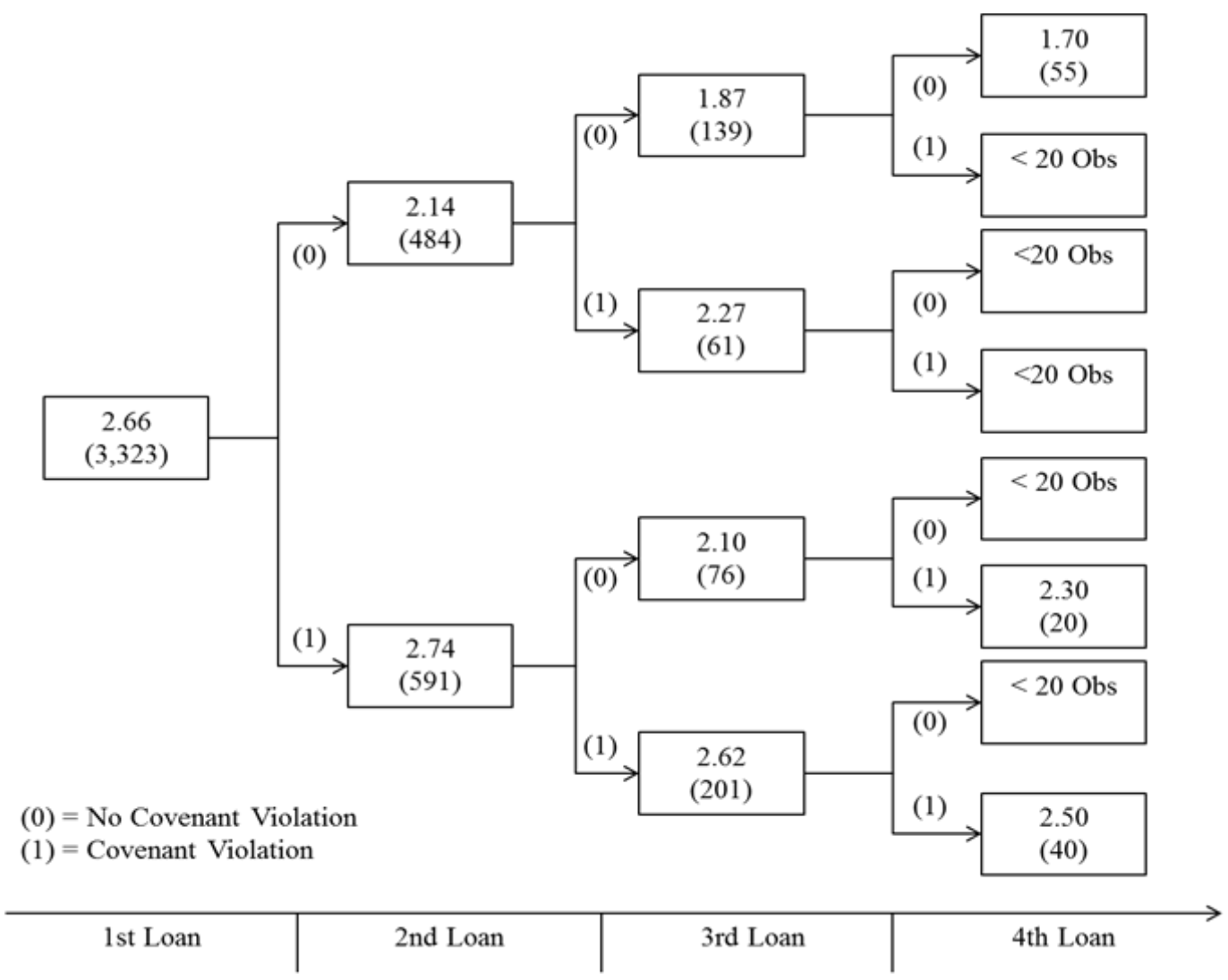




\section{Figure 3}

\section{The Effect of Past Covenant Violations on the Borrower's Probability of Default}

The figure shows the probability of default for the average borrower and for the borrower violating a covenant in the past. "Days since Past Contract Violation" denotes the number of days from the covenant violation in the past contract until the beginning of a new loan contract.

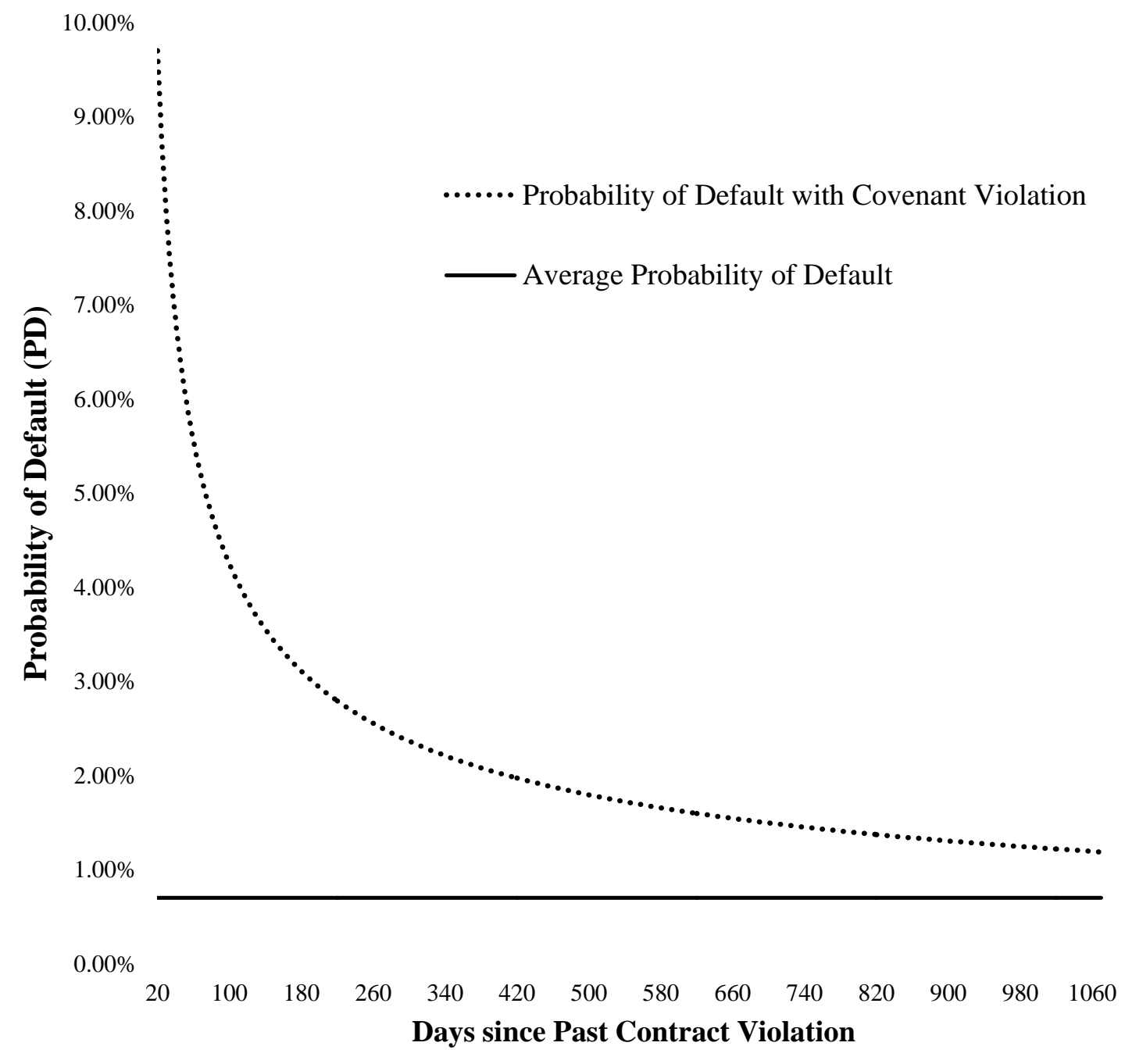




\section{Table I}

\section{Variable Definitions}

\begin{tabular}{|c|c|c|}
\hline Variable & Description & Source \\
\hline \multicolumn{3}{|l|}{ DEPENDENT VARIABLES } \\
\hline All-in-Spread-Drawn & $\begin{array}{l}\text { All-in-Spread-Drawn (in bps) is the coupon spread over LIBOR plus one time fees on } \\
\text { the drawn portion of the loan. }\end{array}$ & LPC Dealscan \\
\hline Number of Financial Covenants & Number of financial covenants per contract. & SEC Filings \\
\hline Covenant Intensity Index & $\begin{array}{l}\text { Index according to Bradley and Roberts (2004) ranging from } 0 \text { to } 6 \text {. It is calculated as } \\
\text { the sum of dummy variables for dividend restriction, asset-, equity-, debt sweep, } \\
\text { secured, and } 2 \text { financial covenants or more. }\end{array}$ & LPC Dealscan \\
\hline Contract Violation & $\begin{array}{l}\text { Dummy variable equal to one if the borrower violates at least one of the financial } \\
\text { covenants in the loan agreement. }\end{array}$ & Own Calculation \\
\hline Days to Contract Violation & Days from contract initiation date until the first financial covenant violation. & Own Calculation \\
\hline Default & Dummy variable equal to one if the borrower defaults. & UCLA Bankruptcy \\
\hline \multicolumn{3}{|l|}{ INDEPENDENT VARIABLES } \\
\hline \multicolumn{3}{|l|}{ Loan Characteristics } \\
\hline Switch & $\begin{array}{l}\text { Dummy variable equal to one for the first loan from this lender or if the borrower did } \\
\text { not obtain a loan from the same lender over at least one year after the previous loan } \\
\text { from this lender matured. }\end{array}$ & LPC Dealscan, NIC \\
\hline Previous Covenant Violation & $\begin{array}{l}\text { Dummy variable equal to one if the borrower violated a covenant in the previous loan of } \\
\text { our sample. }\end{array}$ & Own Calculation \\
\hline Facility Size & Facility amount of the loan in year $2000 \$$ million. & LPC Dealscan \\
\hline Maturity (Months) & Maturity of the loan in months. & LPC Dealscan \\
\hline Secured & Dummy variable equal to one if the loan is secured. & LPC Dealscan \\
\hline \multicolumn{3}{|l|}{ Loan Purpose } \\
\hline Corporate & Dummy variable equal to one, if the loan issuance purpose is "General" in the database. & LPC Dealscan \\
\hline Recapitalization & $\begin{array}{l}\text { Dummy variable equal to one, if the loan issuance purpose is "Recapitalization" in the } \\
\text { database. }\end{array}$ & LPC Dealscan \\
\hline Acquisition & $\begin{array}{l}\text { Dummy variable equal to one, if the loan issuance purpose is "Acquisition" in the } \\
\text { database. }\end{array}$ & LPC Dealscan \\
\hline LBO & $\begin{array}{l}\text { Dummy variable equal to one, if the loan issuance purpose is "Leveraged Buy Out" in } \\
\text { the database. }\end{array}$ & LPC Dealscan \\
\hline Back Up & Dummy variable equal to one, if the loan issuance purpose is "Back Up" in the database. & LPC Dealscan \\
\hline Other & Dummy variable equal to one, if the loan issuance purpose is "Other" in the database. & LPC Dealscan \\
\hline \multicolumn{3}{|l|}{$\underline{\text { Loan Type }}$} \\
\hline Revolver $<1$ Year & Dummy variable equal to one, if the loan type is "Revolver $<1$ Year" in the database. & LPC Dealscan \\
\hline Revolver $\geq 1$ Year & Dummy variable equal to one, if the loan type is "Revolver $\geq 1$ Year" in the database. & LPC Dealscan \\
\hline Bridge Loan & Dummy variable equal to one, if the loan type is "Bridge Loan" in the database. & LPC Dealscan \\
\hline 364 - Day Facility & Dummy variable equal to one, if the loan type is "364 - Day Facility" in the database. & LPC Dealscan \\
\hline Term Loan & Dummy variable equal to one, if the loan type is "Term Loan" in the database. & LPC Dealscan \\
\hline \multicolumn{3}{|l|}{ Borrower Characteristics } \\
\hline Total Assets & Total assets of the borrower in year $2000 \$$ million. & Compustat \\
\hline Profitability & Ratio of EBITDA to sales. & Compustat \\
\hline Current Ratio & Ratio of current assets to current liabilities. & Compustat \\
\hline Leverage Ratio & Ratio of book value of total debt to book value of total assets. & Compustat \\
\hline Coverage & Ratio of EBITDA to interest expenses. & Compustat \\
\hline Market to Book & $\begin{array}{l}\text { Ratio of the sum of book value of liabilities and market value of equity to book value of } \\
\text { total assets. }\end{array}$ & Compustat \\
\hline Borrower IPO (Years) & Years since the IPO of the borrower. & Compustat \\
\hline \multicolumn{3}{|l|}{ Rating } \\
\hline Investment Grade Rating & $\begin{array}{l}\text { Dummy variable equal to one, if the borrower's S\&P long-term issuer rating is BBB- or } \\
\text { better. }\end{array}$ & LPC Dealscan \\
\hline Non-Investment Grade Rating & $\begin{array}{l}\text { Dummy variable equal to one, if the borrower's } \mathrm{S} \& \mathrm{P} \text { long-term issuer rating is } \mathrm{BB}+\text { or } \\
\text { worse. }\end{array}$ & LPC Dealscan \\
\hline Not Rated & Dummy variable equal to one, if the borrower is not rated by $S \& P$. & LPC Dealscan \\
\hline
\end{tabular}




\section{Table I continued Variable Definitions}

\begin{tabular}{lll}
\hline \hline \multicolumn{1}{c}{ Variable } & & Description \\
\hline Financial Covenant Types & & Source \\
\hline Debt Service Coverage Ratio & EBITDA to Interest Expense and Principal Payment & SEC Filings \\
Fixed Charge Coverage Ratio & EBITDA to Interest Expense, Principal Payment, Income Tax and Dividend on Preferred & SEC Filings \\
& Stock & SEC Filings \\
Interest Coverage Ratio & EBITDA to Interest Expense & SEC Filings \\
Debt to Capitalization & Debt to Capitalization (Total Debt and Equity) & SEC Filings \\
Senior Debt to Capitalization & Senior Debt to Capitalization (Total Debt and Equity) & SEC Filings \\
Debt to EBITDA & Debt to EBITDA & SEC Filings \\
Senior Debt to EBITDA & Senior Debt to EBITDA & SEC Filings \\
Debt to Net Worth & Debt to Net Worth & SEC Filings \\
Senior Debt to Net Worth & Senior Debt to Net Worth & SEC Filings \\
Current Ratio & Current Assets to Current Liabilities & SEC Filings \\
Asset Coverage Ratio & Current Assets to Liabilities & SEC Filings \\
Quick Ratio & Current Assets minus Inventory to Current Liabilities & SEC Filings \\
Net Worth & Net Worth & SEC Filings \\
Tangible Net Worth & Tangible Net Worth & SEC Filings \\
EBITDA & EBITDA & SEC Filings \\
Working Capital & Current Assets minus Current Liabilities & SEC Filings \\
Cash and Cash Equivalents & Cash and Cash Equivalents & \\
\hline \hline
\end{tabular}




\section{Table II \\ Descriptive Statistics}

The table shows descriptive statistics of loan and borrower characteristics for loans originated in the 1996 to 2010 period. Borrower data is from the year prior to loan origination. Detailed definitions of the variables are provided in Table I. All variables are winsorized at the 1\% and $99 \%$ level.

\begin{tabular}{|c|c|c|c|c|c|c|}
\hline & Obs & Mean & Std. Dev. & P 5 & Median & P 95 \\
\hline \multicolumn{7}{|l|}{ Panel A: Dependent Variables } \\
\hline All-in-Spread-Drawn & 5,315 & 183 & 124 & 30 & 162 & 400 \\
\hline Number of Financial Covenants & 5,163 & 2.55 & 1.16 & 1 & 2 & 4 \\
\hline Covenant Intensity Index & 1,985 & 4.55 & 1.66 & 1 & 5 & 6 \\
\hline Contract Violation & 5,163 & $55.0 \%$ & $49.8 \%$ & - & - & - \\
\hline Days to Contract Violation & 3,023 & 427 & 397 & 96 & 288 & 1223 \\
\hline Default & 5,411 & $2.5 \%$ & $15.7 \%$ & - & - & - \\
\hline \multicolumn{7}{|l|}{ Panel B: Independent Variables } \\
\hline \multicolumn{7}{|l|}{ B.1 Loan Characteristics } \\
\hline Switch & 5,346 & $35.1 \%$ & $47.7 \%$ & - & - & - \\
\hline Previous Covenant Violation & 2,971 & $57.2 \%$ & $49.5 \%$ & - & - & - \\
\hline Facility Size (Year 2000 USD mm) & 5,411 & 298 & 415 & 11 & 151 & 1,139 \\
\hline Maturity (Months) & 5,349 & 48 & 22 & 12 & 57 & 84 \\
\hline Secured & 5,371 & $63.6 \%$ & $48.1 \%$ & - & - & - \\
\hline \multicolumn{7}{|l|}{ Loan Purpose in $\%$ of Firms } \\
\hline Corporate & 5,411 & $45.7 \%$ & $49.8 \%$ & - & - & - \\
\hline Recapitalization & 5,411 & $21.5 \%$ & $41.1 \%$ & - & - & - \\
\hline Acquisition & 5,411 & $19.9 \%$ & $39.9 \%$ & - & - & - \\
\hline Back Up & 5,411 & $6.5 \%$ & $24.7 \%$ & - & - & - \\
\hline Other & 5,411 & $4.9 \%$ & $21.6 \%$ & - & - & - \\
\hline LBO & 5,411 & $1.6 \%$ & $12.4 \%$ & - & - & - \\
\hline \multicolumn{7}{|l|}{ Loan Type in $\%$ of Firms } \\
\hline Revolver $\geq 1$ Year & 5,411 & $60.2 \%$ & $49.0 \%$ & - & - & - \\
\hline Term Loans & 5,411 & $26.3 \%$ & $44.0 \%$ & - & - & - \\
\hline 364 - Day Facility & 5,411 & $9.1 \%$ & $28.7 \%$ & - & - & - \\
\hline Revolver $<1$ Year & 5,411 & $2.1 \%$ & $14.2 \%$ & - & - & - \\
\hline Bridge Loan & 5,411 & $1.6 \%$ & $12.6 \%$ & - & - & - \\
\hline \multicolumn{7}{|l|}{ B.2 Borrower Characteristics } \\
\hline Total Assets (Year 2000 USD mm) & 5,409 & 3,291 & 6,667 & 65 & 854 & 17,155 \\
\hline Profitability & 5,376 & 0.17 & 0.14 & 0.01 & 0.14 & 0.46 \\
\hline Current Ratio & 5,333 & 1.84 & 1.12 & 0.58 & 1.59 & 3.83 \\
\hline Leverage & 5,401 & 0.33 & 0.22 & 0.007 & 0.30 & 0.73 \\
\hline Coverage & 5,241 & 15.44 & 40.75 & 0.39 & 4.48 & 66.67 \\
\hline Market to Book & 5,330 & 1.68 & 0.89 & 0.85 & 1.40 & 3.45 \\
\hline Borrower IPO (Years) & 4,476 & 45 & 46 & 1.61 & 12.96 & 104.96 \\
\hline \multicolumn{7}{|l|}{ Credit Rating } \\
\hline Investment Grade Rating & 5,411 & $24.1 \%$ & $42.8 \%$ & - & - & - \\
\hline Non-Investment Grade Rating & 5,411 & $34.5 \%$ & $47.5 \%$ & - & - & - \\
\hline Not Rated & 5,411 & $41.4 \%$ & $49.3 \%$ & - & - & - \\
\hline
\end{tabular}




\section{Table III \\ Descriptive Statistics by Covenant Violation in the Previous Loan Contract}

The table shows the mean and median of loan and borrower characteristics for granted loans in the time period 1996 to 2010 split into whether a covenant was violated in the previous loan ("Covenant Violation") or no covenant violation ("No Covenant Violation") occurred. The statistical significance of the difference between "Covenant Violation" and "No Covenant Violation" of the respective variable is tested via a t-test and a Wilcoxon rank sum test where the last two columns provide the corresponding tand z-statistic. All variables are defined in Table I. The statistical significance of results is indicated by $*$ $=10 \%$ level, $* *=5 \%$ level and $* * *=1 \%$ level.

\begin{tabular}{|c|c|c|c|c|c|c|}
\hline & \multirow{2}{*}{\multicolumn{2}{|c|}{$\begin{array}{c}\text { No Violation } \\
\text { (A) }\end{array}$}} & \multirow{2}{*}{\multicolumn{2}{|c|}{$\frac{\text { Violation }}{(\text { B })}$}} & & \\
\hline & & & & & \multicolumn{2}{|c|}{$(A)-(B)$} \\
\hline & Mean & Median & Mean & Median & t-statistics & z-statistics \\
\hline \multicolumn{7}{|l|}{ Panel A: Dependent Variables } \\
\hline All-in-Spread-Drawn & 131 & 100 & 229 & 220 & $-21.920 * * *$ & $-23.140 * * *$ \\
\hline Number of Financial Covenants & 2.02 & 2 & 2.62 & 3 & $-15.030 * * *$ & $-14.600 * * *$ \\
\hline Covenant Intensity Index & 4.57 & 5 & 5.12 & 5 & $-5.340 * * *$ & $-4.430 * * *$ \\
\hline Contract Violation & 0.28 & 0 & 0.70 & 1 & $-24.630 * * *$ & $-22.340 * * *$ \\
\hline Days to Contract Violation & 493 & 399 & 414 & 206 & $2.960 * * *$ & $1.690 *$ \\
\hline Default & 0.008 & 0 & 0.041 & 0 & $-5.350 * * *$ & $-5.330 * * *$ \\
\hline \multicolumn{7}{|l|}{ Panel B: Independent Variables } \\
\hline \multicolumn{7}{|l|}{ B.1 Loan Characteristics } \\
\hline Switch & 0.20 & 0 & 0.28 & 0 & $-5.160 * * *$ & $-5.140 * * *$ \\
\hline Facility Size (Year 2000 USD mm) & 428 & 252 & 287 & 155 & $8.670 * * *$ & $10.600 * * *$ \\
\hline Maturity (Months) & 44.0 & 50.0 & 51.0 & 60.0 & $-8.730 * * *$ & $-7.520 * * *$ \\
\hline Secured & 0.40 & 0 & 0.79 & 1 & $-23.200 * * *$ & $-21.330 * * *$ \\
\hline \multicolumn{7}{|l|}{ Loan Purpose in $\%$ of Firms } \\
\hline Corporate & 0.61 & 1 & 0.48 & 0 & $7.340 * * *$ & $7.270 * * *$ \\
\hline Recapitalization & 0.10 & 0 & 0.16 & 0 & $-4.430 * * *$ & $-4.410 * * *$ \\
\hline Acquisition & 0.09 & 0 & 0.25 & 0 & $-11.530 * * *$ & $-11.280 * * *$ \\
\hline Back Up & 0.12 & 0 & 0.02 & 0 & $11.090^{* * *}$ & $10.870 * * *$ \\
\hline Other & 0.04 & 0 & 0.05 & 0 & -1.64 & -1.64 \\
\hline LBO & 0.02 & 0 & 0.02 & 0 & -0.51 & -0.51 \\
\hline \multicolumn{7}{|l|}{ Loan Type in $\%$ of Firms } \\
\hline Revolver $\geq 1$ Year & 0.64 & 1 & 0.56 & 1 & $4.380 * * *$ & $4.360 * * *$ \\
\hline Term Loans & 0.16 & 0 & 0.36 & 0 & $-11.680 * * *$ & $-11.430 * * *$ \\
\hline 364 - Day Facility & 0.15 & 0 & 0.04 & 0 & $9.910 * * *$ & $9.750 * * *$ \\
\hline Revolver $<1$ Year & 0.02 & 0 & 0.02 & 0 & 0.48 & 0.48 \\
\hline Bridge Loan & 0.02 & 0 & 0.02 & 0 & 0.77 & 0.77 \\
\hline \multicolumn{7}{|l|}{ B.2 Borrower Characteristics } \\
\hline Total Assets (Year 2000 USD mm) & 5,737 & 2,161 & 2,938 & 907 & $10.510 * * *$ & $13.530 * * *$ \\
\hline Profitability & 0.18 & 0.16 & 0.17 & 0.14 & $1.920 * *$ & $3.510 * * *$ \\
\hline Current Ratio & 1.68 & 1.50 & 1.71 & 1.53 & -0.98 & -1.37 \\
\hline Leverage & 0.28 & 0.26 & 0.38 & 0.37 & $-13.470 * * *$ & $-13.800 * * *$ \\
\hline Coverage & 17.96 & 6.68 & 10.01 & 3.57 & $6.460 * * *$ & $15.550 * * *$ \\
\hline Market to Book & 1.68 & 1.41 & 1.57 & 1.33 & $6.740 * * *$ & $5.990 * * *$ \\
\hline Borrower IPO (Years) & 50 & 17 & 42 & 13 & $4.640 * * *$ & $6.240 * * *$ \\
\hline \multicolumn{7}{|l|}{ Credit Rating } \\
\hline Investment Grade Rating & 0.47 & 0 & 0.13 & 0 & $21.530 * * *$ & $20.030 * * *$ \\
\hline Non-Investment Grade Rating & 0.24 & 0 & 0.53 & 1 & $-16.850 * * *$ & $-16.100 * * *$ \\
\hline Not Rated & 0.29 & 0 & 0.34 & 0 & $-2.290 * *$ & $-2.280 * *$ \\
\hline
\end{tabular}




\section{Table IV}

\section{The Effect of Repeated Borrowing on Loan Characteristics}

The tables show descriptive statistics of loan characteristics sorted by the number of loans. In Panel A the loan order is based on repeated borrowing from the same lender. In Panel B loans are sorted by repeated borrowing only irrespective of the lender. All variables are defined in Table I.

Panel A: Repeated Borrowing from Same Lender

\begin{tabular}{ccccccc}
\hline \hline $\begin{array}{c}\text { Number } \\
\text { Loans }\end{array}$ & $\begin{array}{c}\text { Number } \\
\text { Facilities }\end{array}$ & $\begin{array}{c}\text { All-in-Spread- } \\
\text { Drawn }\end{array}$ & $\begin{array}{c}\text { Covenant } \\
\text { Intensity }\end{array}$ & $\begin{array}{c}\text { Number of } \\
\text { Covenants }\end{array}$ & $\begin{array}{c}\text { Contract } \\
\text { Violation }\end{array}$ & $\begin{array}{c}\text { Financial } \\
\text { Default }\end{array}$ \\
\hline 1 & 3,441 & 193 & 4.43 & 2.66 & 0.57 & 0.024 \\
2 & 1,157 & 175 & 4.85 & 2.47 & 0.55 & 0.033 \\
3 & 506 & 159 & 5.07 & 2.31 & 0.49 & 0.025 \\
$>=4$ & 307 & 153 & 4.86 & 1.98 & 0.43 & 0.013 \\
& & & & & & \\
Total & 5,411 & 183 & 4.55 & 2.55 & 0.55 & 0.025 \\
\hline \hline
\end{tabular}

Panel B: Repeated Borrowing Only

\begin{tabular}{ccccccc}
\hline \hline $\begin{array}{c}\text { Number } \\
\text { Loans }\end{array}$ & $\begin{array}{c}\text { Number } \\
\text { Facilities }\end{array}$ & $\begin{array}{c}\text { All-in-Spread- } \\
\text { Drawn }\end{array}$ & $\begin{array}{c}\text { Covenant } \\
\text { Intensity }\end{array}$ & $\begin{array}{c}\text { Number of } \\
\text { Covenants }\end{array}$ & $\begin{array}{c}\text { Contract } \\
\text { Violation }\end{array}$ & $\begin{array}{c}\text { Financial } \\
\text { Default }\end{array}$ \\
\hline 1 & 2,354 & 178 & 4.17 & 2.79 & 0.59 & 0.022 \\
2 & 1,422 & 193 & 4.90 & 2.55 & 0.57 & 0.030 \\
3 & 818 & 182 & 5.20 & 2.34 & 0.49 & 0.025 \\
$>=4$ & 817 & 184 & 5.11 & 2.04 & 0.46 & 0.027 \\
& & & & & & 0.55 \\
Total & 5,411 & 183 & 4.55 & 2.55 & & 0.025 \\
\hline \hline
\end{tabular}




\section{Table V}

\section{Covenant Violations and Loan Contract Terms}

The table reports results from multivariate regressions of different dependent variables. These are the (1) All-in-Spread-Drawn, (2) number of financial covenants, (3) covenant intensity, (4) contract violation and (5) days to contract violation. Previous covenant violation is a dummy variable equal to one if the borrower violated a financial covenant in the previous loan contract. All variables are described in Table I. In Model (3) "Secured" is excluded as it is part of the dependent variable. Standard errors shown in parentheses are robust to heteroscedasticity and clustered at the firm level. The statistical significance of results is indicated by $*=10 \%$ level, $* *=5 \%$ level and $* * *=1 \%$ level.

\begin{tabular}{|c|c|c|c|c|c|}
\hline & (1) & (2) & (3) & (4) & (5) \\
\hline Dependent Variable & AISD & $\begin{array}{l}\text { Covenant } \\
\text { Number }\end{array}$ & $\begin{array}{l}\text { Covenant } \\
\text { Intensity }\end{array}$ & $\begin{array}{l}\text { Contract } \\
\text { Violation }\end{array}$ & $\begin{array}{c}\text { Days to } \\
\text { Contract } \\
\text { Violation }\end{array}$ \\
\hline Regression Methodology & OLS & Ordered Logit & Ordered Logit & Logit & OLS \\
\hline Previous Covenant Violation & $\begin{array}{c}21.899 * * * \\
(4.178)\end{array}$ & $\begin{array}{c}0.403 * * * \\
(0.108)\end{array}$ & $\begin{array}{l}0.418 * \\
(0.235)\end{array}$ & $\begin{array}{c}1.263 * * * \\
(0.156)\end{array}$ & $\begin{array}{c}-123.663 * * * \\
(39.732)\end{array}$ \\
\hline \multicolumn{6}{|l|}{ Loan Characteristics } \\
\hline Maturity (Months) & $\begin{array}{c}-0.512 * * * \\
(0.172)\end{array}$ & $\begin{array}{l}0.006 * \\
(0.004)\end{array}$ & $\begin{array}{c}0.017 * * * \\
(0.006)\end{array}$ & $\begin{array}{c}0.006 \\
(0.005)\end{array}$ & $\begin{array}{c}4.092 * * * \\
(0.953)\end{array}$ \\
\hline Secured & $\begin{array}{c}56.309 * * * \\
(5.798)\end{array}$ & $\begin{array}{l}-0.029 \\
(0.132)\end{array}$ & & $\begin{array}{c}0.105 \\
(0.183)\end{array}$ & $\begin{array}{l}-24.042 \\
(34.805)\end{array}$ \\
\hline Log (Facility Size) & $\begin{array}{c}-15.091 * * * \\
(2.699)\end{array}$ & $\begin{array}{c}0.069 \\
(0.056)\end{array}$ & $\begin{array}{l}-0.163 \\
(0.123)\end{array}$ & $\begin{array}{l}0.146^{*} \\
(0.080)\end{array}$ & $\begin{array}{l}-29.153 \\
(19.047)\end{array}$ \\
\hline \multicolumn{6}{|l|}{ Borrower Characteristics } \\
\hline Profitability & $\begin{array}{c}-0.719 * * * \\
(0.246)\end{array}$ & $\begin{array}{c}0.006 \\
(0.005)\end{array}$ & $\begin{array}{c}0.009 \\
(0.009)\end{array}$ & $\begin{array}{c}0.001 \\
(0.007)\end{array}$ & $\begin{array}{c}1.040 \\
(1.258)\end{array}$ \\
\hline Current Ratio & $\begin{array}{c}-0.058 * * \\
(0.025)\end{array}$ & $\begin{array}{c}0.001 \\
(0.001)\end{array}$ & $\begin{array}{c}-0.002 * \\
(0.001)\end{array}$ & $\begin{array}{c}0.000 \\
(0.001)\end{array}$ & $\begin{array}{l}-0.017 \\
(0.160)\end{array}$ \\
\hline Leverage & $\begin{array}{c}0.916^{* * * *} \\
(0.147)\end{array}$ & $\begin{array}{l}-0.000 \\
(0.004)\end{array}$ & $\begin{array}{c}0.001 \\
(0.006)\end{array}$ & $\begin{array}{c}0.011 * * \\
(0.005)\end{array}$ & $\begin{array}{l}-0.503 \\
(0.777)\end{array}$ \\
\hline Coverage & $\begin{array}{l}-0.001 * \\
(0.000)\end{array}$ & $\begin{array}{c}0.000 \\
(0.000)\end{array}$ & $\begin{array}{c}0.000 * * \\
(0.000)\end{array}$ & $\begin{array}{l}-0.000 \\
(0.000)\end{array}$ & $\begin{array}{c}0.003 \\
(0.004)\end{array}$ \\
\hline Market to Book & $\begin{array}{c}-0.127 * * * \\
(0.027)\end{array}$ & $\begin{array}{l}-0.000 \\
(0.001)\end{array}$ & $\begin{array}{c}-0.005^{* * * *} \\
(0.001)\end{array}$ & $\begin{array}{c}-0.002 * * \\
(0.001)\end{array}$ & $\begin{array}{l}-0.123 \\
(0.238)\end{array}$ \\
\hline Log (Total Assets) & $\begin{array}{l}-4.077 \\
(2.943)\end{array}$ & $\begin{array}{c}-0.421 * * * \\
(0.070)\end{array}$ & $\begin{array}{l}-0.233 * \\
(0.136)\end{array}$ & $\begin{array}{l}-0.155^{*} \\
(0.092)\end{array}$ & $\begin{array}{c}12.694 \\
(16.856)\end{array}$ \\
\hline Rating & & & & & \\
\hline Investment Grade Rating & $\begin{array}{c}-46.196 * * * \\
(7.970)\end{array}$ & $\begin{array}{c}-0.929 * * * \\
(0.197)\end{array}$ & $\begin{array}{l}-0.827 \\
(0.648)\end{array}$ & $\begin{array}{c}-0.825 * * * \\
(0.226)\end{array}$ & $\begin{array}{l}-18.852 \\
(49.956)\end{array}$ \\
\hline Not Rated & $\begin{array}{c}-24.013 * * * \\
(7.299)\end{array}$ & $\begin{array}{l}-0.198 \\
(0.184)\end{array}$ & $\begin{array}{c}-0.539 * \\
(0.294)\end{array}$ & $\begin{array}{l}-0.080 \\
(0.215)\end{array}$ & $\begin{array}{l}-38.623 \\
(43.520)\end{array}$ \\
\hline Constant & $\begin{array}{c}440.607 * * * \\
(39.989)\end{array}$ & YES & YES & $\begin{array}{c}1.160 \\
(2.062) \\
\end{array}$ & $\begin{array}{c}297.734 \\
(222.270) \\
\end{array}$ \\
\hline Year Fixed Effects & YES & YES & YES & YES & YES \\
\hline Industry Fixed Effects & YES & YES & YES & YES & YES \\
\hline Loan Type Fixed Effects & YES & YES & YES & YES & YES \\
\hline Loan Purpose Fixed Effects & YES & YES & YES & YES & YES \\
\hline Number of Observations & 2786 & 2709 & 848 & 1934 & 1039 \\
\hline $\mathrm{R}^{2}$ & 0.634 & 0.143 & 0.172 & 0.225 & 0.191 \\
\hline
\end{tabular}




\section{Table VI}

\section{Switching and Loan Contract Terms}

The table reports results from multivariate regressions of different dependent variables. These are the (1) All-in-Spread-Drawn, (2) number of financial covenants, (3) covenant intensity, (4) contract violation and (5) days to contract violation. Switch is a dummy variable equal to one for the first loan from this lender or if the borrower did not obtain a loan from the same lender over at least one year after the previous loan from this lender matured. All variables are described in Table I. In Model (3) "Secured" is excluded as it is part of the dependent variable. Standard errors shown in parentheses are robust to heteroscedasticity and clustered at the firm level. The statistical significance of results is indicated by $*=10 \%$ level, $* *=5 \%$ level and $* * *=1 \%$ level.

\begin{tabular}{|c|c|c|c|c|c|}
\hline & $(1)$ & $(2)$ & (3) & $(4)$ & (5) \\
\hline Dependent Variable & AISD & $\begin{array}{l}\text { Covenant } \\
\text { Number }\end{array}$ & $\begin{array}{l}\text { Covenant } \\
\text { Intensity }\end{array}$ & $\begin{array}{l}\text { Contract } \\
\text { Violation }\end{array}$ & $\begin{array}{c}\text { Days to } \\
\text { Contract } \\
\text { Violation } \\
\end{array}$ \\
\hline Regression Methodology & OLS & Ordered Logit & Ordered Logit & Logit & OLS \\
\hline Switch & $\begin{array}{c}11.997 * * * \\
(3.377)\end{array}$ & $\begin{array}{c}-0.148 * \\
(0.089)\end{array}$ & $\begin{array}{c}0.076 \\
(0.147)\end{array}$ & $\begin{array}{l}-0.108 \\
(0.108)\end{array}$ & $\begin{array}{c}-64.740 * * * \\
(24.938)\end{array}$ \\
\hline \multicolumn{6}{|l|}{ Loan Characteristics } \\
\hline Maturity (Months) & $\begin{array}{c}-0.487 * * * \\
(0.126)\end{array}$ & $\begin{array}{l}0.005^{*} \\
(0.003)\end{array}$ & $\begin{array}{c}0.011^{* * * *} \\
(0.004)\end{array}$ & $\begin{array}{c}0.007 * * \\
(0.003)\end{array}$ & $\begin{array}{c}4.049 * * * \\
(0.847)\end{array}$ \\
\hline Secured & $\begin{array}{c}65.283 * * * \\
(3.963)\end{array}$ & $\begin{array}{c}0.247 * * \\
(0.097)\end{array}$ & & $\begin{array}{c}0.558 * * * \\
(0.121)\end{array}$ & $\begin{array}{c}-124.993 * * * \\
(33.605)\end{array}$ \\
\hline Log (Facility Size) & $\begin{array}{c}-14.626 * * * \\
(1.998)\end{array}$ & $\begin{array}{l}0.078 * \\
(0.046)\end{array}$ & $\begin{array}{l}-0.095 \\
(0.079)\end{array}$ & $\begin{array}{c}0.023 \\
(0.055)\end{array}$ & $\begin{array}{l}-21.804 * \\
(11.681)\end{array}$ \\
\hline \multicolumn{6}{|l|}{ Borrower Characteristics } \\
\hline Profitability & $\begin{array}{c}-0.943 * * * \\
(0.181)\end{array}$ & $\begin{array}{c}0.005 \\
(0.004)\end{array}$ & $\begin{array}{c}0.008 \\
(0.006)\end{array}$ & $\begin{array}{l}-0.004 \\
(0.004)\end{array}$ & $\begin{array}{c}1.196 \\
(0.875)\end{array}$ \\
\hline Current Ratio & $\begin{array}{c}-0.044 * * \\
(0.017)\end{array}$ & $\begin{array}{l}0.001 * \\
(0.000)\end{array}$ & $\begin{array}{l}-0.001 * \\
(0.001)\end{array}$ & $\begin{array}{c}0.001 \\
(0.000)\end{array}$ & $\begin{array}{l}-0.052 \\
(0.106)\end{array}$ \\
\hline Leverage & $\begin{array}{c}0.992 * * * \\
(0.112)\end{array}$ & $\begin{array}{l}-0.001 \\
(0.003)\end{array}$ & $\begin{array}{c}0.006 \\
(0.004)\end{array}$ & $\begin{array}{c}0.010^{* * * *} \\
(0.003)\end{array}$ & $\begin{array}{l}-0.497 \\
(0.639)\end{array}$ \\
\hline Coverage & $\begin{array}{c}-0.001 * * \\
(0.000)\end{array}$ & $\begin{array}{l}-0.000 \\
(0.000)\end{array}$ & $\begin{array}{l}-0.000 * \\
(0.000)\end{array}$ & $\begin{array}{l}-0.000 \\
(0.000)\end{array}$ & $\begin{array}{l}-0.002 \\
(0.003)\end{array}$ \\
\hline Market to Book & $\begin{array}{c}-0.095^{* * * *} \\
(0.018)\end{array}$ & $\begin{array}{l}-0.001 \\
(0.001)\end{array}$ & $\begin{array}{l}-0.002 * \\
(0.001)\end{array}$ & $\begin{array}{l}-0.001 \\
(0.001)\end{array}$ & $\begin{array}{c}0.086 \\
(0.141)\end{array}$ \\
\hline Log (Total Assets) & $\begin{array}{l}-3.128 \\
(2.252)\end{array}$ & $\begin{array}{c}-0.365^{* * *} \\
(0.055)\end{array}$ & $\begin{array}{c}-0.244 * * \\
(0.096)\end{array}$ & $\begin{array}{l}-0.087 \\
(0.063)\end{array}$ & $\begin{array}{c}15.819 \\
(12.767)\end{array}$ \\
\hline Rating & & & & & \\
\hline Investment Grade Rating & $\begin{array}{c}-45.998 * * * \\
(5.825)\end{array}$ & $\begin{array}{c}-1.013 * * * \\
(0.151)\end{array}$ & $\begin{array}{c}-1.573 * * * \\
(0.349)\end{array}$ & $\begin{array}{c}-0.796 * * * \\
(0.174)\end{array}$ & $\begin{array}{l}-22.529 \\
(41.998)\end{array}$ \\
\hline Not Rated & $\begin{array}{c}-23.432 * * * \\
(5.379)\end{array}$ & $\begin{array}{c}-0.289 * * \\
(0.137)\end{array}$ & $\begin{array}{c}-0.448 * * \\
(0.189)\end{array}$ & $\begin{array}{c}-0.257^{*} \\
(0.151)\end{array}$ & $\begin{array}{l}-16.751 \\
(34.349)\end{array}$ \\
\hline Constant & $\begin{array}{c}508.284 * * * \\
(43.617)\end{array}$ & YES & YES & $\begin{array}{l}-1.388 \\
(1.215) \\
\end{array}$ & $\begin{array}{c}166.705 \\
(164.543)\end{array}$ \\
\hline Year Fixed Effects & YES & YES & YES & YES & YES \\
\hline Industry Fixed Effects & YES & YES & YES & YES & YES \\
\hline Loan Type Fixed Effects & YES & YES & YES & YES & YES \\
\hline Loan Purpose Fixed Effects & YES & YES & YES & YES & YES \\
\hline $\begin{array}{l}\text { Number of Observations } \\
\mathrm{R}^{2}\end{array}$ & $\begin{array}{l}4846 \\
0.612\end{array}$ & $\begin{array}{l}4732 \\
0.127\end{array}$ & $\begin{array}{l}1821 \\
0.181\end{array}$ & $\begin{array}{l}3934 \\
0.141\end{array}$ & $\begin{array}{l}2232 \\
0.118\end{array}$ \\
\hline
\end{tabular}




\section{Table VII}

\section{Covenant Violations, Switching and Loan Spreads}

The table reports results from OLS regressions relating the All-in-Spread-Drawn to Previous Covenant Violations and Switching. Previous covenant violation is a dummy variable equal to one if the borrower violated a financial covenant in the previous loan contract. Switch is a dummy variable equal to one for the first loan from this lender or if the borrower did not obtain a loan from the same lender over at least one year after the previous loan from this lender matured. There are 3 proxies for borrower opacity: young ( $<3$ years public), small $\left(<25^{\text {th }}\right.$ percentile total assets), and not rated firms (no S\&P long-term issuer rating). All variables are described in Table I. Standard errors shown in parentheses are robust to heteroscedasticity and clustered at the firm level. The statistical significance of results is indicated by $*=$ $10 \%$ level, $* *=5 \%$ level and $* * *=1 \%$ level.

\begin{tabular}{|c|c|c|c|c|c|c|c|}
\hline & (1) & (2) & (3) & (4) & (5) & (6) & (7) \\
\hline Switch & $\begin{array}{c}11.997 * * * \\
(3.377)\end{array}$ & & $\begin{array}{c}12.355 * * \\
(4.920)\end{array}$ & $\begin{array}{c}15.904 * * \\
(6.711)\end{array}$ & $\begin{array}{c}18.579 * * * \\
(7.011)\end{array}$ & $\begin{array}{c}19.342 * * * \\
(7.120)\end{array}$ & $\begin{array}{c}22.963 * * * \\
(7.888)\end{array}$ \\
\hline Previous Covenant Violation & & $\begin{array}{c}21.899 * * * \\
(4.178)\end{array}$ & $\begin{array}{c}22.666^{* * * *} \\
(4.128)\end{array}$ & $\begin{array}{c}23.986 * * * \\
(4.258)\end{array}$ & $\begin{array}{c}25.195 * * * \\
(4.435)\end{array}$ & $\begin{array}{c}22.636^{* * * *} \\
(4.352)\end{array}$ & $\begin{array}{c}11.443 * * \\
(5.258)\end{array}$ \\
\hline Switch * Previous Covenant Violation & & & & $\begin{array}{c}-5.649 \\
(9.207)\end{array}$ & $\begin{array}{l}-4.215 \\
(9.686)\end{array}$ & $\begin{array}{r}-12.181 \\
(9.881)\end{array}$ & $\begin{array}{c}-11.445 \\
(10.920)\end{array}$ \\
\hline Borrower Opacity & & & & & Young & Small & Not Rated \\
\hline Opaque Firm & & & & & $\begin{array}{l}31.631^{* * *} \\
(12.455)\end{array}$ & $\begin{array}{c}17.671 \\
(14.335)\end{array}$ & $\begin{array}{c}-41.425 * * * \\
(8.062)\end{array}$ \\
\hline Opaque Firm * Switch & & & & & $\begin{array}{l}-19.890 \\
(16.709)\end{array}$ & $\begin{array}{l}-14.648 \\
(24.804)\end{array}$ & $\begin{array}{c}-24.032^{*} \\
(13.148)\end{array}$ \\
\hline Opaque Firm * Previous Violation & & & & & $\begin{array}{c}-4.658 \\
(16.512)\end{array}$ & $\begin{array}{c}13.873 \\
(18.270)\end{array}$ & $\begin{array}{c}33.587 * * * \\
(9.261)\end{array}$ \\
\hline Opaque Firm * Switch * Previous Violation & & & & & $\begin{array}{c}-28.114 \\
(24.707)\end{array}$ & $\begin{array}{c}23.944 \\
(31.082)\end{array}$ & $\begin{array}{c}19.016 \\
(19.192) \\
\end{array}$ \\
\hline Loan Characteristics & & & & & & & \\
\hline Maturity (Months) & $\begin{array}{c}-0.487 * * * \\
(0.126)\end{array}$ & $\begin{array}{c}-0.512 * * * \\
(0.172)\end{array}$ & $\begin{array}{c}-0.514 * * * \\
(0.174)\end{array}$ & $\begin{array}{c}-0.512 * * * \\
(0.174)\end{array}$ & $\begin{array}{c}-0.459^{* * *} * \\
(0.175)\end{array}$ & $\begin{array}{c}-0.414 * * \\
(0.173)\end{array}$ & $\begin{array}{c}-0.505^{* * *} * \\
(0.173)\end{array}$ \\
\hline Secured & $\begin{array}{c}65.283 * * * * \\
(3.963)\end{array}$ & $\begin{array}{c}56.309 * * * \\
(5.798)\end{array}$ & $\begin{array}{c}56.180^{* * * *} \\
(5.571)\end{array}$ & $\begin{array}{c}56.287 * * * \\
(5.577)\end{array}$ & $\begin{array}{c}60.080 * * * \\
(5.385)\end{array}$ & $\begin{array}{c}61.256^{* * * *} \\
(5.367)\end{array}$ & $\begin{array}{c}55.160 * * * * \\
(5.496)\end{array}$ \\
\hline Log (Facility Size) & $\begin{array}{c}-14.626 * * * \\
(1.998)\end{array}$ & $\begin{array}{c}-15.091 * * * \\
(2.699)\end{array}$ & $\begin{array}{c}-14.929 * * * \\
(2.730)\end{array}$ & $\begin{array}{c}-14.963 * * * \\
(2.738)\end{array}$ & $\begin{array}{c}-14.644 * * * \\
(2.720)\end{array}$ & $\begin{array}{c}-13.995 * * * \\
(2.740)\end{array}$ & $\begin{array}{c}-14.872 * * * \\
(2.720)\end{array}$ \\
\hline Borrower Characteristics & & & & & & & \\
\hline Profitability & $\begin{array}{c}-0.943^{* * *} \\
(0.181)\end{array}$ & $\begin{array}{c}-0.719 * * * \\
(0.246)\end{array}$ & $\begin{array}{c}-0.739 * * * \\
(0.245)\end{array}$ & $\begin{array}{c}-0.737 * * * \\
(0.245)\end{array}$ & $\begin{array}{c}-0.721 * * * \\
(0.240)\end{array}$ & $\begin{array}{c}-0.715^{* * * *} \\
(0.236)\end{array}$ & $\begin{array}{c}-0.745^{* * *} * \\
(0.244)\end{array}$ \\
\hline Current Ratio & $\begin{array}{c}-0.044 * * \\
(0.017)\end{array}$ & $\begin{array}{c}-0.058^{* *} * \\
(0.025)\end{array}$ & $\begin{array}{c}-0.055^{* *} \\
(0.025)\end{array}$ & $\begin{array}{c}-0.056^{* *} \\
(0.025)\end{array}$ & $\begin{array}{c}-0.057 * * \\
(0.025)\end{array}$ & $\begin{array}{c}-0.048^{*} \\
(0.025)\end{array}$ & $\begin{array}{c}-0.053 * * \\
(0.025)\end{array}$ \\
\hline Leverage & $\begin{array}{c}0.992 * * * \\
(0.112)\end{array}$ & $\begin{array}{c}0.916 * * * \\
(0.147)\end{array}$ & $\begin{array}{c}0.906 * * * \\
(0.147)\end{array}$ & $\begin{array}{c}0.908 * * * \\
(0.147)\end{array}$ & $\begin{array}{c}1.017 * * * \\
(0.139)\end{array}$ & $\begin{array}{c}1.007 * * * \\
(0.140)\end{array}$ & $\begin{array}{c}0.914 * * * \\
(0.144)\end{array}$ \\
\hline Coverage & $\begin{array}{l}-0.001 * * \\
(3.2 \mathrm{E}-04)\end{array}$ & $\begin{array}{c}-0.001^{*} \\
(4.9 \mathrm{E}-04)\end{array}$ & $\begin{array}{c}-0.001 * \\
(4.9 \mathrm{E}-04)\end{array}$ & $\begin{array}{c}-0.001^{*} \\
(4.9 \mathrm{E}-04)\end{array}$ & $\begin{array}{c}-0.001 * * \\
(0.001)\end{array}$ & $\begin{array}{l}-0.001 * * \\
(4.9 \mathrm{E}-04)\end{array}$ & $\begin{array}{l}-0.001 \\
(0.001)\end{array}$ \\
\hline Market to Book & $\begin{array}{c}-0.095^{* * *} * \\
(0.018)\end{array}$ & $\begin{array}{c}-0.127 * * * \\
(0.027)\end{array}$ & $\begin{array}{c}-0.124 * * * \\
(0.027)\end{array}$ & $\begin{array}{c}-0.123 * * * \\
(0.027)\end{array}$ & $\begin{array}{c}-0.121 * * * \\
(0.027)\end{array}$ & $\begin{array}{c}-0.111 * * * \\
(0.027)\end{array}$ & $\begin{array}{c}-0.122 * * * \\
(0.027)\end{array}$ \\
\hline Log (Total Assets) & $\begin{array}{l}-3.128 \\
(2.252)\end{array}$ & $\begin{array}{l}-4.077 \\
(2.943)\end{array}$ & $\begin{array}{c}-2.951 \\
(2.944)\end{array}$ & $\begin{array}{c}-2.981 \\
(2.946)\end{array}$ & $\begin{array}{c}0.662 \\
(2.837)\end{array}$ & $\begin{array}{l}5.346^{*} \\
(2.891)\end{array}$ & $\begin{array}{c}-2.376 \\
(2.921)\end{array}$ \\
\hline Rating & & & & & & & \\
\hline Investment Grade Rating & $\begin{array}{c}-45.998 * * * \\
(5.825)\end{array}$ & $\begin{array}{c}-46.196 * * * \\
(7.970)\end{array}$ & $\begin{array}{c}-44.439 * * * \\
(7.854)\end{array}$ & $\begin{array}{c}-44.267 * * * \\
(7.842)\end{array}$ & $\begin{array}{c}-36.294 * * * \\
(6.842)\end{array}$ & $\begin{array}{c}-39.999 * * * \\
(7.122)\end{array}$ & $\begin{array}{c}-51.798 * * * \\
(7.958)\end{array}$ \\
\hline Not Rated & $\begin{array}{c}-23.432 * * * \\
(5.379)\end{array}$ & $\begin{array}{c}-24.013 * * * \\
(7.299)\end{array}$ & $\begin{array}{c}-22.246 * * * \\
(7.025)\end{array}$ & $\begin{array}{c}-22.181 * * * \\
(7.022)\end{array}$ & & & \\
\hline Constant & $\begin{array}{c}508.284 * * * \\
(43.617)\end{array}$ & $\begin{array}{c}440.607 * * * \\
(39.989)\end{array}$ & $\begin{array}{c}401.601 * * * \\
(39.047)\end{array}$ & $\begin{array}{c}401.204 * * * \\
(39.072)\end{array}$ & $\begin{array}{c}332.208 * * * \\
(36.461)\end{array}$ & $\begin{array}{c}292.059 * * * \\
(39.925)\end{array}$ & $\begin{array}{c}407.542 * * * \\
(39.544)\end{array}$ \\
\hline Year Fixed Effects & YES & YES & YES & YES & YES & YES & YES \\
\hline Industry Fixed Effects & YES & YES & YES & YES & YES & YES & YES \\
\hline Loan Type Fixed Effects & YES & YES & YES & YES & YES & YES & YES \\
\hline Loan Purpose Fixed Effects & YES & YES & YES & YES & YES & YES & YES \\
\hline Number of Observations & 4846 & 2786 & 2740 & 2740 & 2740 & 2740 & 2740 \\
\hline $\mathrm{R}^{2}$ & 0.612 & 0.634 & 0.640 & 0.641 & 0.640 & 0.642 & 0.645 \\
\hline
\end{tabular}




\section{Table VIII}

\section{Covenant Violations, Switching and the Number of Financial Covenants}

The table reports results from ordered logit regressions relating the number of financial covenants to Previous Covenant Violations and Switching. Previous covenant violation is a dummy variable equal to one if the borrower violated a financial covenant in the previous loan contract. Switch is a dummy variable equal to one for the first loan from this lender or if the borrower did not obtain a loan from the same lender over at least one year after the previous loan from this lender matured. There are 3 proxies for borrower opacity: young ( $<3$ years public), small $\left(<25^{\text {th }}\right.$ percentile total assets), and not rated firms (no S\&P long-term issuer rating). All variables are described in Table I. Standard errors shown in parentheses are robust to heteroscedasticity and clustered at the firm level. The statistical significance of results is indicated by $*=10 \%$ level, $* *=5 \%$ level and $* * *=1 \%$ level.

\begin{tabular}{|c|c|c|c|c|c|c|c|}
\hline & (1) & (2) & (3) & (4) & (5) & (6) & (7) \\
\hline Switch & $\begin{array}{c}-0.148^{*} \\
(0.089)\end{array}$ & & $\begin{array}{l}-0.216 \\
(0.132)\end{array}$ & $\begin{array}{l}-0.260 \\
(0.158)\end{array}$ & $\begin{array}{l}-0.167 \\
(0.160)\end{array}$ & $\begin{array}{l}-0.166 \\
(0.161)\end{array}$ & $\begin{array}{l}-0.183 \\
(0.180)\end{array}$ \\
\hline Previous Covenant Violation & & $\begin{array}{c}0.403 * * * \\
(0.108)\end{array}$ & $\begin{array}{c}0.430 * * * \\
(0.107)\end{array}$ & $\begin{array}{c}0.415 * * * \\
(0.120)\end{array}$ & $\begin{array}{c}0.453 * * * \\
(0.121)\end{array}$ & $\begin{array}{c}0.409 * * * \\
(0.125)\end{array}$ & $\begin{array}{c}0.496 * * * \\
(0.152)\end{array}$ \\
\hline Switch * Previous Covenant Violation & & & & $\begin{array}{c}0.070 \\
(0.226)\end{array}$ & $\begin{array}{c}-0.022 \\
(0.229)\end{array}$ & $\begin{array}{c}0.142 \\
(0.242)\end{array}$ & $\begin{array}{c}0.068 \\
(0.266)\end{array}$ \\
\hline Borrower Opacity & & & & & Young & Small & Not Rated \\
\hline Opaque Firm & & & & & $\begin{array}{c}0.418 \\
(0.335)\end{array}$ & $\begin{array}{l}-0.063 \\
(0.337)\end{array}$ & $\begin{array}{l}-0.043 \\
(0.234)\end{array}$ \\
\hline Opaque Firm * Switch & & & & & $\begin{array}{c}-2.706^{* * * *} \\
(0.745)\end{array}$ & $\begin{array}{l}-0.550 \\
(0.540)\end{array}$ & $\begin{array}{l}-0.227 \\
(0.361)\end{array}$ \\
\hline Opaque Firm * Previous Violation & & & & & $\begin{array}{l}-0.416 \\
(0.621)\end{array}$ & $\begin{array}{c}0.048 \\
(0.423)\end{array}$ & $\begin{array}{l}-0.208 \\
(0.254)\end{array}$ \\
\hline Opaque Firm * Switch * Previous Violation & & & & & $\begin{array}{c}2.856^{* * *} \\
(1.128)\end{array}$ & $\begin{array}{l}-0.113 \\
(0.685)\end{array}$ & $\begin{array}{c}0.025 \\
(0.502)\end{array}$ \\
\hline Loan Characteristics & & & & & & & \\
\hline Maturity (Months) & $\begin{array}{l}0.005^{*} \\
(0.003)\end{array}$ & $\begin{array}{l}0.006 * \\
(0.004)\end{array}$ & $\begin{array}{c}0.006 \\
(0.004)\end{array}$ & $\begin{array}{c}0.006 \\
(0.004)\end{array}$ & $\begin{array}{l}0.007 * \\
(0.004)\end{array}$ & $\begin{array}{l}0.007 * \\
(0.004)\end{array}$ & $\begin{array}{c}0.006 \\
(0.004)\end{array}$ \\
\hline Secured & $\begin{array}{c}0.247 * * \\
(0.097)\end{array}$ & $\begin{array}{l}-0.029 \\
(0.132)\end{array}$ & $\begin{array}{l}-0.040 \\
(0.132)\end{array}$ & $\begin{array}{l}-0.041 \\
(0.132)\end{array}$ & $\begin{array}{c}-0.002 \\
(0.130)\end{array}$ & $\begin{array}{c}0.007 \\
(0.130)\end{array}$ & $\begin{array}{l}-0.029 \\
(0.133)\end{array}$ \\
\hline Log (Facility Size) & $\begin{array}{l}0.078^{*} \\
(0.046)\end{array}$ & $\begin{array}{c}0.069 \\
(0.056)\end{array}$ & $\begin{array}{c}0.071 \\
(0.057)\end{array}$ & $\begin{array}{c}0.071 \\
(0.057)\end{array}$ & $\begin{array}{c}0.077 \\
(0.058)\end{array}$ & $\begin{array}{c}0.073 \\
(0.057)\end{array}$ & $\begin{array}{c}0.068 \\
(0.057)\end{array}$ \\
\hline Borrower Characteristics & & & & & & & \\
\hline Profitability & $\begin{array}{c}0.005 \\
(0.004)\end{array}$ & $\begin{array}{c}0.006 \\
(0.005)\end{array}$ & $\begin{array}{c}0.006 \\
(0.005)\end{array}$ & $\begin{array}{c}0.006 \\
(0.005)\end{array}$ & $\begin{array}{c}0.006 \\
(0.005)\end{array}$ & $\begin{array}{c}0.006 \\
(0.005)\end{array}$ & $\begin{array}{c}0.006 \\
(0.005)\end{array}$ \\
\hline Current Ratio & $\begin{array}{c}0.001^{*} \\
(4.4 \mathrm{E}-04)\end{array}$ & $\begin{array}{c}0.001 \\
(0.001)\end{array}$ & $\begin{array}{c}0.001 \\
(0.001)\end{array}$ & $\begin{array}{c}0.001 \\
(0.001)\end{array}$ & $\begin{array}{c}0.001 \\
(0.001)\end{array}$ & $\begin{array}{c}0.001 \\
(0.001)\end{array}$ & $\begin{array}{c}0.001 \\
(0.001)\end{array}$ \\
\hline Leverage & $\begin{array}{l}-0.001 \\
(0.003)\end{array}$ & $\begin{array}{c}-9.53 \mathrm{E}-06 \\
(0.004)\end{array}$ & $\begin{array}{c}2.42 \mathrm{E}-04 \\
(0.004)\end{array}$ & $\begin{array}{c}2.20 \mathrm{E}-04 \\
(0.004)\end{array}$ & $\begin{array}{c}0.001 \\
(0.004)\end{array}$ & $\begin{array}{c}0.001 \\
(0.003)\end{array}$ & $\begin{array}{c}0.000 \\
(0.004)\end{array}$ \\
\hline Coverage & $\begin{array}{c}-9.12 \mathrm{E}-06 \\
(7.6 \mathrm{E}-06)\end{array}$ & $\begin{array}{l}8.36 \mathrm{E}-06 \\
(1.4 \mathrm{E}-05)\end{array}$ & $\begin{array}{l}1.07 \mathrm{E}-05 \\
(1.4 \mathrm{E}-05)\end{array}$ & $\begin{array}{l}1.08 \mathrm{E}-05 \\
(1.4 \mathrm{E}-05)\end{array}$ & $\begin{array}{l}7.19 \mathrm{E}-06 \\
(1.4 \mathrm{E}-05)\end{array}$ & $\begin{array}{l}7.75 \mathrm{E}-06 \\
(1.4 \mathrm{E}-05)\end{array}$ & $\begin{array}{l}1.07 \mathrm{E}-05 \\
(1.4 \mathrm{E}-05)\end{array}$ \\
\hline Market to Book & $\begin{array}{c}-7.62 \mathrm{E}-04 \\
(0.001)\end{array}$ & $\begin{array}{c}-3.50 \mathrm{E}-04 \\
(0.001)\end{array}$ & $\begin{array}{c}-4.40 \mathrm{E}-04 \\
(0.001)\end{array}$ & $\begin{array}{c}-4.45 \mathrm{E}-04 \\
(0.001)\end{array}$ & $\begin{array}{c}-4.64 \mathrm{E}-04 \\
(0.001)\end{array}$ & $\begin{array}{c}-5.61 \mathrm{E}-04 \\
(0.001)\end{array}$ & $\begin{array}{c}-4.86 \mathrm{E}-04 \\
(0.001)\end{array}$ \\
\hline Log (Total Assets) & $\begin{array}{c}-0.365 * * * \\
(0.055)\end{array}$ & $\begin{array}{c}-0.421 * * * \\
(0.070)\end{array}$ & $\begin{array}{c}-0.435 * * * \\
(0.072)\end{array}$ & $\begin{array}{c}-0.434 * * * \\
(0.072)\end{array}$ & $\begin{array}{c}-0.402 * * * \\
(0.070)\end{array}$ & $\begin{array}{c}-0.446 * * * \\
(0.077)\end{array}$ & $\begin{array}{c}-0.438 * * * \\
(0.072)\end{array}$ \\
\hline Rating & & & & & & & \\
\hline Investment Grade Rating & $\begin{array}{c}-1.013 * * * \\
(0.151)\end{array}$ & $\begin{array}{c}-0.929 * * * \\
(0.197)\end{array}$ & $\begin{array}{c}-0.941 * * * \\
(0.199)\end{array}$ & $\begin{array}{c}-0.943 * * * \\
(0.199)\end{array}$ & $\begin{array}{c}-0.852 * * * \\
(0.179)\end{array}$ & $\begin{array}{c}-0.827 * * * \\
(0.178)\end{array}$ & $\begin{array}{c}-0.886^{* * * *} \\
(0.204)\end{array}$ \\
\hline Not Rated & $\begin{array}{c}-0.289 * * \\
(0.137)\end{array}$ & $\begin{array}{c}-0.198 \\
(0.184)\end{array}$ & $\begin{array}{c}-0.227 \\
(0.185)\end{array}$ & $\begin{array}{c}-0.229 \\
(0.185)\end{array}$ & & & \\
\hline Constant & YES & YES & YES & YES & YES & YES & YES \\
\hline Year Fixed Effects & YES & YES & YES & YES & YES & YES & YES \\
\hline Industry Fixed Effects & YES & YES & YES & YES & YES & YES & YES \\
\hline Loan Type Fixed Effects & YES & YES & YES & YES & YES & YES & YES \\
\hline Loan Purpose Fixed Effects & YES & YES & YES & YES & YES & YES & YES \\
\hline $\begin{array}{l}\text { Number of Observations } \\
R^{2}\end{array}$ & $\begin{array}{l}4732 \\
0.127\end{array}$ & $\begin{array}{l}2709 \\
0.143\end{array}$ & $\begin{array}{l}2665 \\
0.145\end{array}$ & $\begin{array}{l}2665 \\
0.145\end{array}$ & $\begin{array}{l}2665 \\
0.146\end{array}$ & $\begin{array}{l}2665 \\
0.146\end{array}$ & $\begin{array}{l}2665 \\
0.145\end{array}$ \\
\hline
\end{tabular}




\section{Table IX}

\section{Covenant Violations, Switching and Covenant Intensity}

The table reports results from ordered logit regressions relating Bradley and Roberts (2004) covenant intensity index to Previous Covenant Violations and Switching. Previous covenant violation is a dummy variable equal to one if the borrower violated a financial covenant in the previous loan contract. Switch is a dummy variable equal to one for the first loan from this lender or if the borrower did not obtain a loan from the same lender over at least one year after the previous loan from this lender matured. There are 3 proxies for borrower opacity: young $\left(<3\right.$ years public), small $\left(<25^{\text {th }}\right.$ percentile total assets), and not rated firms (no S\&P long-term issuer rating). All variables are described in Table I. Standard errors shown in parentheses are robust to heteroscedasticity and clustered at the firm level. The statistical significance of results is indicated by $*=10 \%$ level, $* *=5 \%$ level and $* * *=1 \%$ level.

\begin{tabular}{|c|c|c|c|c|c|c|c|}
\hline & (1) & (2) & (3) & (4) & (5) & (6) & (7) \\
\hline \multirow[t]{2}{*}{ Switch } & 0.076 & & 0.181 & 0.632 & 0.642 & 0.830 & $1.418 * *$ \\
\hline & $(0.147)$ & & $(0.260)$ & $(0.445)$ & $(0.470)$ & $(0.533)$ & $(0.581)$ \\
\hline Previous Covenant Violation & & $0.418 *$ & $0.441 *$ & $0.582 * *$ & $0.631 * *$ & $0.857 * * *$ & $1.123 * * *$ \\
\hline \multirow[t]{2}{*}{ Switch * Previous Covenant Violation } & & & & -0.575 & -0.628 & -1.011 & $-1.825 * * *$ \\
\hline & & & & $(0.526)$ & $(0.547)$ & $(0.633)$ & $(0.666)$ \\
\hline \multirow[t]{2}{*}{ Opaque Firm } & & & & & 0.140 & 0.473 & 0.336 \\
\hline & & & & & $(0.628)$ & $(0.958)$ & $(0.514)$ \\
\hline \multirow[t]{2}{*}{ Opaque Firm * Switch } & & & & & 0.992 & -1.175 & $-2.076 * * *$ \\
\hline & & & & & $(0.938)$ & $(1.224)$ & $(0.778)$ \\
\hline \multirow[t]{2}{*}{ Opaque Firm * Previous Violation } & & & & & -0.667 & -1.631 & $-1.460 * *$ \\
\hline & & & & & $(0.827)$ & $(1.013)$ & $(0.568)$ \\
\hline \multirow[t]{2}{*}{ Opaque Firm * Switch * Previous Violation } & & & & & & $2.352^{*}$ & $3.497 * * *$ \\
\hline & & & & & & $(1.389)$ & $(0.947)$ \\
\hline \multirow[t]{2}{*}{ Maturity (Months) } & $0.011 * * *$ & $0.017 * * *$ & $0.015 * *$ & $0.015 * *$ & $0.018 * * *$ & $0.017 * * *$ & $0.015^{* *}$ \\
\hline & $(0.004)$ & $(0.006)$ & $(0.007)$ & $(0.007)$ & $(0.006)$ & $(0.006)$ & $(0.007)$ \\
\hline \multirow[t]{2}{*}{ Log (Facility Size) } & -0.095 & -0.163 & -0.148 & -0.148 & -0.151 & -0.177 & -0.125 \\
\hline & $(0.079)$ & $(0.123)$ & $(0.124)$ & $(0.125)$ & $(0.129)$ & $(0.120)$ & $(0.126)$ \\
\hline \multicolumn{8}{|l|}{ Borrower Characteristics } \\
\hline \multirow{2}{*}{ Profitability } & 0.008 & 0.009 & 0.008 & 0.008 & 0.009 & 0.008 & 0.009 \\
\hline & $(0.006)$ & $(0.009)$ & $(0.009)$ & $(0.009)$ & $(0.009)$ & $(0.009)$ & $(0.009)$ \\
\hline \multirow[t]{2}{*}{ Current Ratio } & $-0.001 *$ & $-0.002 *$ & $-0.002 *$ & $-0.002 *$ & $-0.002 *$ & $-0.002 *$ & $-0.002 *$ \\
\hline & $(0.001)$ & $(0.001)$ & $(0.001)$ & $(0.001)$ & $(0.001)$ & $(0.001)$ & $(0.001)$ \\
\hline \multirow[t]{2}{*}{ Leverage } & 0.006 & 0.001 & $1.01 \mathrm{E}-04$ & $-3.13 \mathrm{E}-05$ & 0.003 & 0.003 & -0.001 \\
\hline & $(0.004)$ & $(0.006)$ & $(0.006)$ & $(0.006)$ & $(0.005)$ & $(0.005)$ & $(0.006)$ \\
\hline \multirow[t]{2}{*}{ Coverage } & $-3.48 \mathrm{E}-05^{*}$ & $1.17 \mathrm{E}-04 * *$ & $1.10 \mathrm{E}-04 * *$ & $1.15 \mathrm{E}-04 * *$ & $1.06 \mathrm{E}-04 * *$ & $1.15 \mathrm{E}-04 * *$ & $1.07 \mathrm{E}-04 * *$ \\
\hline & $(2.1 \mathrm{E}-05)$ & $(5.3 \mathrm{E}-05)$ & (5.3E-05) & $(5.2 \mathrm{E}-05)$ & (5.1E-05) & (5.3E-05) & $(5.2 \mathrm{E}-05)$ \\
\hline \multirow[t]{2}{*}{ Market to Book } & $-0.002 *$ & $-0.005 * * *$ & $-0.005 * * *$ & $-0.005^{* * *}$ & $-0.005 * * *$ & $-0.005^{* * *} *$ & $-0.006 * * *$ \\
\hline & $(0.001)$ & $(0.001)$ & $(0.001)$ & $(0.001)$ & $(0.002)$ & $(0.001)$ & $(0.001)$ \\
\hline Log (Total Assets) & $-0.244 * *$ & $-0.233^{*}$ & -0.222 & -0.230 & -0.120 & -0.269 & $-0.263^{*}$ \\
\hline \multicolumn{8}{|l|}{ Rating } \\
\hline \multirow[t]{2}{*}{ Investment Grade Rating } & $-1.573 * * *$ & -0.827 & -0.887 & -0.886 & -0.806 & -0.651 & -0.918 \\
\hline & $(0.349)$ & $(0.648)$ & $(0.670)$ & $(0.668)$ & $(0.688)$ & $(0.696)$ & $(0.663)$ \\
\hline \multirow[t]{2}{*}{ Not Rated } & $-0.448 * *$ & $-0.539 *$ & $-0.579 *$ & $-0.596 * *$ & & & \\
\hline & $(0.189)$ & $(0.294)$ & $(0.297)$ & $(0.301)$ & & & \\
\hline Constant & YES & YES & YES & YES & YES & YES & YES \\
\hline Year Fixed Effects & YES & YES & YES & YES & YES & YES & YES \\
\hline Industry Fixed Effects & YES & YES & YES & YES & YES & YES & YES \\
\hline Loan Type Fixed Effects & YES & YES & YES & YES & YES & YES & YES \\
\hline Loan Purpose Fixed Effects & YES & YES & YES & YES & YES & YES & YES \\
\hline Number of Observations & 1821 & 848 & 826 & 826 & 826 & 826 & 826 \\
\hline $\mathrm{R}^{2}$ & 0.181 & 0.172 & 0.173 & 0.174 & 0.172 & 0.178 & 0.184 \\
\hline
\end{tabular}




\section{Table X}

\section{Covenant Violations, Switching and the Propensity for Subsequent Violations}

The table reports results from logit regressions relating the propensity for covenant violations in the current contract to Previous Covenant Violations and Switching. Previous covenant violation is a dummy variable equal to one if the borrower violated a financial covenant in the previous loan contract. Switch is a dummy variable equal to one for the first loan from this lender or if the borrower did not obtain a loan from the same lender over at least one year after the previous loan from this lender matured. There are 3 proxies for borrower opacity: young ( $<3$ years public), small $\left(<25^{\text {th }}\right.$ percentile total assets), and not rated firms (no S\&P long-term issuer rating). All variables are described in Table I. Standard errors shown in parentheses are robust to heteroscedasticity and clustered at the firm level. The statistical significance of results is indicated by $*=10 \%$ level, $* *=5 \%$ level and $* * *=1 \%$ level.

\begin{tabular}{|c|c|c|c|c|c|c|c|}
\hline & (1) & (2) & (3) & (4) & (5) & (6) & (7) \\
\hline Switch & $\begin{array}{l}-0.108 \\
(0.108)\end{array}$ & & $\begin{array}{l}-0.225 \\
0.1809\end{array}$ & 0.343 & 0.328 & 0.225 & 0.182 \\
\hline Previous Covenant Violation & & $\begin{array}{c}1.263 * * * \\
(0.156)\end{array}$ & $\begin{array}{c}1.271 * * * \\
(0.159)\end{array}$ & $\begin{array}{c}1.471 * * * \\
(0.181)\end{array}$ & $1.348 * * *$ & $1.491 * * *$ & $1.625^{* * *}$ \\
\hline Switch * Previous Covenant Violation & & & & $\begin{array}{c}-0.851 * * * \\
(0.327)\end{array}$ & $\begin{array}{c}-0.796 * * \\
(0.333)\end{array}$ & $\begin{array}{c}-0.744 * * \\
(0.366)\end{array}$ & $\begin{array}{c}-0.727 * \\
(0.433)\end{array}$ \\
\hline Borrower Opacity & & & & & Young & Small & Not Rated \\
\hline Opaque Firm & & & & & $\begin{array}{l}-0.629 \\
(0.571)\end{array}$ & $\begin{array}{c}0.490 \\
(0.467)\end{array}$ & $\begin{array}{c}0.090 \\
(0.319)\end{array}$ \\
\hline Opaque Firm * Switch & & & & & $\begin{array}{l}-0.802 \\
(1.147)\end{array}$ & $\begin{array}{c}0.414 \\
(0.734)\end{array}$ & $\begin{array}{c}0.325 \\
(0.526)\end{array}$ \\
\hline Opaque Firm * Previous Violation & & & & & $\begin{array}{l}1.585 * * \\
(0.733)\end{array}$ & $\begin{array}{l}-0.223 \\
(0.523)\end{array}$ & $\begin{array}{l}-0.376 \\
(0.360)\end{array}$ \\
\hline Opaque Firm * Switch * Previous Violation & & & & & $\begin{array}{c}0.256 \\
(1.355)\end{array}$ & $\begin{array}{l}-0.232 \\
(0.902)\end{array}$ & $\begin{array}{l}-0.213 \\
(0.676)\end{array}$ \\
\hline Loan Characteristics & & & & & & & \\
\hline Maturity (Months) & $\begin{array}{c}0.007 * * \\
(0.003)\end{array}$ & $\begin{array}{c}0.006 \\
(0.005)\end{array}$ & $\begin{array}{c}0.006 \\
(0.005)\end{array}$ & $\begin{array}{c}0.007 \\
(0.005)\end{array}$ & $\begin{array}{c}0.007 \\
(0.005)\end{array}$ & $\begin{array}{c}0.008 \\
(0.005)\end{array}$ & $\begin{array}{c}0.007 \\
(0.005)\end{array}$ \\
\hline Secured & $\begin{array}{c}0.558 * * * \\
(0.121)\end{array}$ & $\begin{array}{c}0.105 \\
(0.183)\end{array}$ & $\begin{array}{c}0.129 \\
(0.183)\end{array}$ & $\begin{array}{c}0.129 \\
(0.182)\end{array}$ & $\begin{array}{c}0.153 \\
(0.179)\end{array}$ & $\begin{array}{c}0.135 \\
(0.181)\end{array}$ & $\begin{array}{c}0.126 \\
(0.181)\end{array}$ \\
\hline Log (Facility Size) & $\begin{array}{c}0.023 \\
(0.055)\end{array}$ & $\begin{array}{l}0.146^{*} \\
(0.080)\end{array}$ & $\begin{array}{l}0.144 * \\
(0.082)\end{array}$ & $\begin{array}{l}0.143 * \\
(0.083)\end{array}$ & $\begin{array}{l}0.140 * \\
(0.083)\end{array}$ & $\begin{array}{l}0.151^{*} \\
(0.083)\end{array}$ & $\begin{array}{l}0.143 * \\
(0.083)\end{array}$ \\
\hline Borrower Characteristics & & & & & & & \\
\hline Profitability & $\begin{array}{l}-0.004 \\
(0.004)\end{array}$ & $\begin{array}{c}0.001 \\
(0.007)\end{array}$ & $\begin{array}{c}0.001 \\
(0.007)\end{array}$ & $\begin{array}{c}0.001 \\
(0.007)\end{array}$ & $\begin{array}{c}0.000 \\
(0.007)\end{array}$ & $\begin{array}{c}0.001 \\
(0.007)\end{array}$ & $\begin{array}{c}0.001 \\
(0.007)\end{array}$ \\
\hline Current Ratio & $\begin{array}{c}0.001 \\
(0.000)\end{array}$ & $\begin{array}{c}2.65 \mathrm{E}-04 \\
(0.001)\end{array}$ & $\begin{array}{c}3.45 \mathrm{E}-04 \\
(0.001)\end{array}$ & $\begin{array}{c}3.86 \mathrm{E}-04 \\
(0.001)\end{array}$ & $\begin{array}{c}4.73 \mathrm{E}-04 \\
(0.001)\end{array}$ & $\begin{array}{c}4.32 \mathrm{E}-04 \\
(0.001)\end{array}$ & $\begin{array}{c}3.29 \mathrm{E}-04 \\
(0.001)\end{array}$ \\
\hline Leverage & $\begin{array}{c}0.010 * * * \\
(0.003)\end{array}$ & $\begin{array}{c}0.011^{* *} \\
(0.005)\end{array}$ & $\begin{array}{c}0.010 * * \\
(0.005)\end{array}$ & $\begin{array}{c}0.011 * * \\
(0.005)\end{array}$ & $\begin{array}{c}0.011 * * * \\
(0.004)\end{array}$ & $\begin{array}{c}0.012 * * * \\
(0.004)\end{array}$ & $\begin{array}{c}0.011 * * \\
(0.005)\end{array}$ \\
\hline Coverage & $\begin{array}{l}-1.63 \mathrm{E}-05 \\
(1.2 \mathrm{E}-05)\end{array}$ & $\begin{array}{l}-1.11 \mathrm{E}-05 \\
(2.6 \mathrm{E}-05)\end{array}$ & $\begin{array}{l}-1.01 \mathrm{E}-05 \\
(2.6 \mathrm{E}-05)\end{array}$ & $\begin{array}{l}-1.25 \mathrm{E}-05 \\
(2.6 \mathrm{E}-05)\end{array}$ & $\begin{array}{l}-1.07 \mathrm{E}-05 \\
(2.6 \mathrm{E}-05)\end{array}$ & $\begin{array}{l}-1.30 \mathrm{E}-05 \\
(2.5 \mathrm{E}-05)\end{array}$ & $\begin{array}{c}-1.41 \mathrm{E}-05 \\
(2.6 \mathrm{E}-05)\end{array}$ \\
\hline Market to Book & $\begin{array}{l}-0.001 \\
(0.001)\end{array}$ & $\begin{array}{c}-0.002 * * \\
(0.001)\end{array}$ & $\begin{array}{c}-0.002 * * \\
(0.001)\end{array}$ & $\begin{array}{c}-0.002 * \\
(0.001)\end{array}$ & $\begin{array}{c}-0.002 * * \\
(0.001)\end{array}$ & $\begin{array}{c}-0.002 * \\
(0.001)\end{array}$ & $\begin{array}{c}-0.002 * \\
(0.001)\end{array}$ \\
\hline Log (Total Assets) & $\begin{array}{l}-0.087 \\
(0.063)\end{array}$ & $\begin{array}{l}-0.155^{*} \\
(0.092)\end{array}$ & $\begin{array}{l}-0.172^{*} \\
(0.094)\end{array}$ & $\begin{array}{c}-0.177 * \\
(0.094)\end{array}$ & $\begin{array}{l}-0.134 \\
(0.086)\end{array}$ & $\begin{array}{l}-0.079 \\
(0.101)\end{array}$ & $\begin{array}{c}-0.189 * * \\
(0.095)\end{array}$ \\
\hline Rating & & & & & & & \\
\hline Investment Grade Rating & $\begin{array}{c}-0.796 * * * \\
(0.174)\end{array}$ & $\begin{array}{c}-0.825 * * * \\
(0.226)\end{array}$ & $\begin{array}{c}-0.762 * * * \\
(0.226)\end{array}$ & $\begin{array}{c}-0.759 * * * \\
(0.224)\end{array}$ & $\begin{array}{c}-0.748 * * * \\
(0.212)\end{array}$ & $\begin{array}{c}-0.777 * * * * \\
(0.216)\end{array}$ & $\begin{array}{c}-0.705^{* * *} * \\
(0.231)\end{array}$ \\
\hline Not Rated & $\begin{array}{c}-0.257^{*} \\
(0.151)\end{array}$ & $\begin{array}{l}-0.080 \\
(0.215)\end{array}$ & $\begin{array}{l}-0.095 \\
(0.219)\end{array}$ & $\begin{array}{l}-0.097 \\
(0.218)\end{array}$ & & & \\
\hline Constant & $\begin{array}{l}-1.388 \\
(1.215)\end{array}$ & $\begin{array}{l}1.160 \\
(2.062)\end{array}$ & $\begin{array}{c}0.787 \\
(1.567)\end{array}$ & $\begin{array}{c}0.661 \\
(1.546)\end{array}$ & $\begin{array}{c}0.351 \\
(1.403)\end{array}$ & $\begin{array}{l}-0.498 \\
(1.555)\end{array}$ & $\begin{array}{c}0.712 \\
(1.548)\end{array}$ \\
\hline Year Fixed Effects & YES & YES & YES & YES & YES & YES & YES \\
\hline Industry Fixed Effects & YES & YES & YES & YES & YES & YES & YES \\
\hline Loan Type Fixed Effects & YES & YES & YES & YES & YES & YES & YES \\
\hline Loan Purpose Fixed Effects & YES & YES & YES & YES & YES & YES & YES \\
\hline Number of Observations & 3934 & 1934 & 1916 & 1916 & 1916 & 1916 & 1916 \\
\hline $\mathrm{R}^{2}$ & 0.141 & 0.225 & 0.226 & 0.230 & 0.235 & 0.233 & 0.232 \\
\hline
\end{tabular}




\section{Table XI \\ Covenant Violations, Switching and the Days to Subsequent Violations}

The table reports results from hazard rate model regressions relating days to covenant violation in the current contract to Previous Covenant Violations and Switching. Previous Covenant Violation is a dummy variable equal to one if the borrower violated a financial covenant in the previous loan contract. Switch is a dummy variable equal to one for the first loan from this lender or if the borrower did not obtain a loan from the same lender over at least one year after the previous loan from this lender matured. There are 3 proxies for borrower opacity: young ( $<3$ years public), small $\left(<25^{\text {th }}\right.$ percentile total assets), and not rated firms (no S\&P long-term issuer rating). All variables are described in Table I. Standard errors shown in parentheses are robust to heteroscedasticity and clustered at the firm level. The statistical significance of results is indicated by $*=10 \%$ level, $* *=5 \%$ level and $* * *=1 \%$ level.

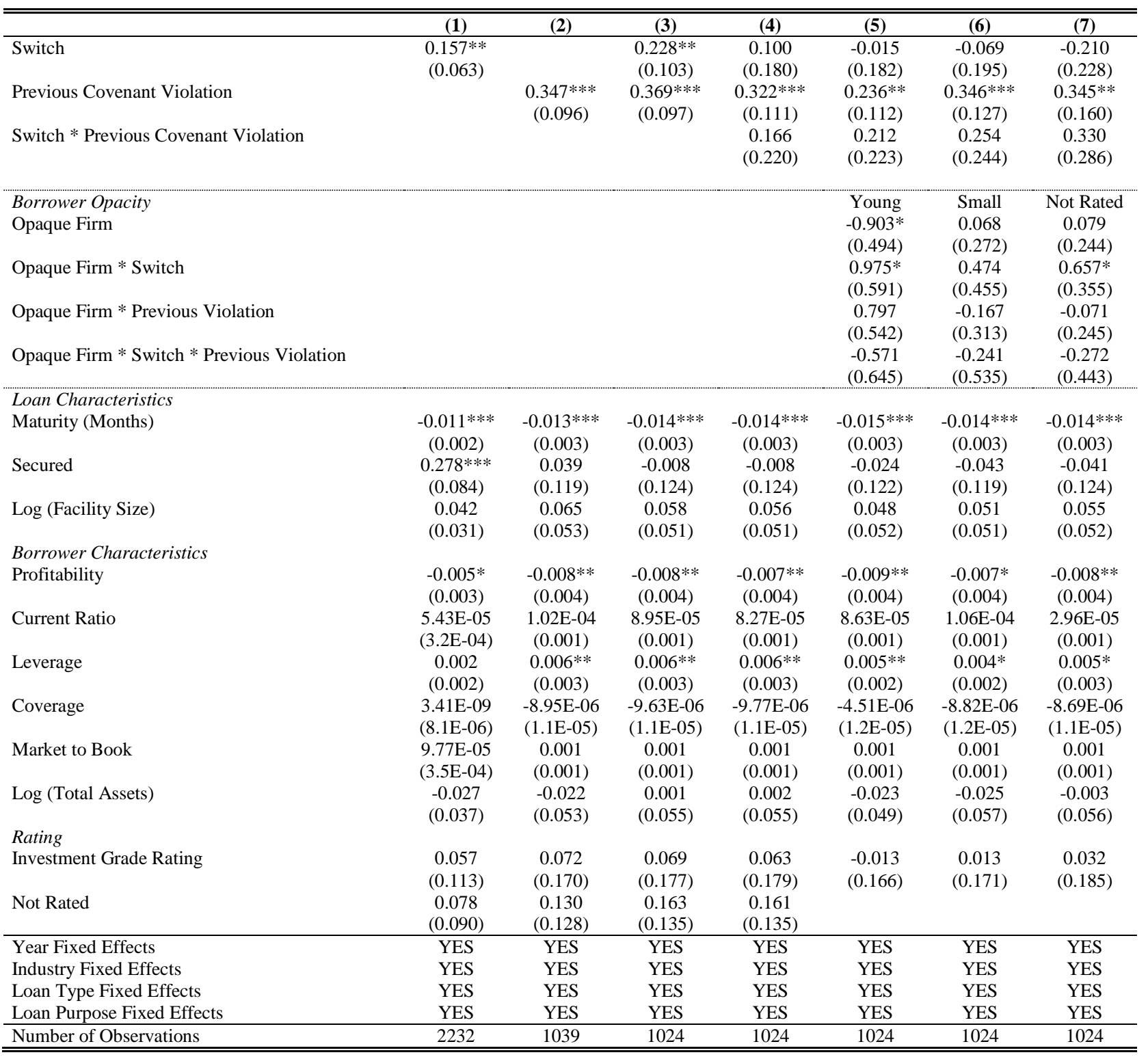




\section{Table XII}

\section{The Impact of Previous Covenant Violation on a Borrower's Likelihood to Default}

The table reports results from logit regressions relating borrower default to Previous Covenant Violations and Switching. We use three different models. In Model 1, previous covenant violation is a dummy variable equal to one if the borrower violated a financial covenant in the previous loan contract. Switch is a dummy variable equal to one for the first loan from this lender or if the borrower did not obtain a loan from the same lender over at least one year after the previous loan from this lender matured. In Model 2, "Covenant Violation in [-1,080; -180] Days prior to Default" is a dummy variable equal to one if the borrower violated a financial covenant in the time period from 1,080 to 180 days prior to default. In Model 3, "Violation in Past Contract" is one when the borrower violated a financial covenant in the respective past loan. "Ln[Days since Past Contract (Covenant Violation)]" is the natural logarithm of the number of days from the end of the respective past loan contract until the current loan under investigation if no financial covenant was violated."Number of Loans with No Cov. Violation" is the number of loans without a financial covenant violation between the respective past loan and the current loan under investigation. All variables are described in Table I. Standard errors shown in parentheses are robust to heteroscedasticity and clustered at the firm level. The statistical significance of results is indicated by $*=10 \%$ level, $* *=$ $5 \%$ level and $* * *=1 \%$ level. 


\begin{tabular}{|c|c|c|c|c|c|c|c|c|c|}
\hline & \multicolumn{4}{|c|}{ Model 1} & \multirow{2}{*}{$\begin{array}{c}\text { Model } 2 \\
(5) \\
\end{array}$} & \multicolumn{4}{|c|}{ Model 3} \\
\hline & (1) & $(2)$ & (3) & (4) & & (6) & (7) & (8) & (9) \\
\hline Switch & $\begin{array}{c}0.130 \\
(0.340)\end{array}$ & & $\begin{array}{c}0.574 \\
(0.523)\end{array}$ & $\begin{array}{c}1.966 \\
(1.655)\end{array}$ & & $\begin{array}{c}0.322 \\
(0.388)\end{array}$ & & $\begin{array}{c}0.936 \\
(0.896)\end{array}$ & $\begin{array}{c}0.891 \\
(0.903)\end{array}$ \\
\hline Previous Covenant Violation & & $\begin{array}{l}1.975^{\text {*** }} \\
(0.949)\end{array}$ & $\begin{array}{l}1.965^{* * *} \\
(0.957)\end{array}$ & $\begin{array}{c}2.473 \text { *** } \\
(1.255)\end{array}$ & & & & & \\
\hline Switch * Previous Covenant Violation & & & & $\begin{array}{l}-1.510 \\
(1.803)\end{array}$ & & & & & \\
\hline Covenant Violation in $[-1,080 ;-180]$ Days prior to Default & & & & & $\begin{array}{c}2.951 * * * \\
(0.788)\end{array}$ & & & & \\
\hline Violation in Past Contract & & & & & & & $\begin{array}{c}26.383 * * * \\
(6.991)\end{array}$ & $\begin{array}{c}26.551 * * * \\
(6.632)\end{array}$ & $\begin{array}{c}29.757 * * * \\
(8.738)\end{array}$ \\
\hline Ln[Days since Past Contract ( Covenant Violation)] & & & & & & & $\begin{array}{c}3.036 * * * \\
(0.909)\end{array}$ & $\begin{array}{c}3.088 * * * \\
(0.854)\end{array}$ & $\begin{array}{c}3.615^{* * *} \\
(1.154)\end{array}$ \\
\hline Violation in Past Contract * Ln[Days since Past Contract & & & & & & & $-3.811 * * *$ & $-3.828 * * *$ & $-4.297 * * *$ \\
\hline (Covenant Violation)] & & & & & & & $(0.944)$ & $(0.914)$ & $(1.207)$ \\
\hline Number of Loans with No Cov. Violation in Between & & & & & & & & & $\begin{array}{r}-1.216 \\
(1.540)\end{array}$ \\
\hline Loan Characteristics & & & & & & & & & \\
\hline Maturity (Months) & $\begin{array}{c}0.026 * * * \\
(0.009)\end{array}$ & $\begin{array}{c}0.030 \\
(0.020)\end{array}$ & $\begin{array}{c}0.029 \\
(0.021)\end{array}$ & $\begin{array}{c}0.030 \\
(0.021)\end{array}$ & $\begin{array}{l}-0.008 \\
(0.008)\end{array}$ & $\begin{array}{c}0.035 * * * \\
(0.009)\end{array}$ & $\begin{array}{c}0.032 \\
(0.022)\end{array}$ & $\begin{array}{c}0.031 \\
(0.025)\end{array}$ & $\begin{array}{c}0.031 \\
(0.026)\end{array}$ \\
\hline Secured & $\begin{array}{c}1.957 * * * \\
(0.495)\end{array}$ & $\begin{array}{l}1.765^{* * *} \\
(0.807)\end{array}$ & $\begin{array}{l}1.813^{* * *} \\
(0.848)\end{array}$ & $\begin{array}{l}1.799 * * \\
(0.858)\end{array}$ & $\begin{array}{l}1.013 * * \\
(0.470)\end{array}$ & $\begin{array}{c}2.278 * * * * \\
(0.571)\end{array}$ & $\begin{array}{c}2.027 \\
(1.243)\end{array}$ & $\begin{array}{c}2.071 \\
(1.275)\end{array}$ & $\begin{array}{c}2.050 \\
(1.301)\end{array}$ \\
\hline Log (Facility Size) & $\begin{array}{c}0.408 * * \\
(0.185)\end{array}$ & $\begin{array}{l}-0.004 \\
(0.236)\end{array}$ & $\begin{array}{c}0.047 \\
(0.241)\end{array}$ & $\begin{array}{c}0.041 \\
(0.241)\end{array}$ & $\begin{array}{c}0.476 * * \\
(0.188)\end{array}$ & $\begin{array}{c}0.518^{* * *} \\
(0.238)\end{array}$ & $\begin{array}{c}0.436 \\
(0.533)\end{array}$ & $\begin{array}{c}0.586 \\
(0.568)\end{array}$ & $\begin{array}{c}0.553 \\
(0.535)\end{array}$ \\
\hline Borrower Characteristics & & & & & & & & & \\
\hline Profitability & $\begin{array}{l}-0.026 \\
(0.017)\end{array}$ & $\begin{array}{c}0.013 \\
(0.026)\end{array}$ & $\begin{array}{c}0.012 \\
(0.025)\end{array}$ & $\begin{array}{c}0.011 \\
(0.025)\end{array}$ & $\begin{array}{c}-0.011 \\
(0.017)\end{array}$ & $\begin{array}{l}-0.022 \\
(0.018)\end{array}$ & $\begin{array}{c}0.045 \\
(0.031)\end{array}$ & $\begin{array}{c}0.039 \\
(0.027)\end{array}$ & $\begin{array}{c}0.048 \\
(0.036)\end{array}$ \\
\hline Current Ratio & $\begin{array}{c}0.005 * * * \\
(0.002)\end{array}$ & $\begin{array}{c}1.31 \mathrm{E}-04 \\
(0.004)\end{array}$ & $\begin{array}{c}4.23 \mathrm{E}-04 \\
(0.004)\end{array}$ & $\begin{array}{c}3.03 \mathrm{E}-04 \\
(0.004)\end{array}$ & $\begin{array}{c}0.002 \\
(0.002)\end{array}$ & $\begin{array}{c}0.005 * * * \\
(0.002)\end{array}$ & $\begin{array}{l}-0.003 \\
(0.006)\end{array}$ & $\begin{array}{l}-0.004 \\
(0.006)\end{array}$ & $\begin{array}{l}-0.003 \\
(0.005)\end{array}$ \\
\hline Leverage & $\begin{array}{c}0.016 \\
(0.011)\end{array}$ & $\begin{array}{l}-0.012 \\
(0.019)\end{array}$ & $\begin{array}{l}-0.008 \\
(0.019)\end{array}$ & $\begin{array}{l}-0.008 \\
(0.019)\end{array}$ & $\begin{array}{c}0.000 * * * \\
(0.000)\end{array}$ & $\begin{array}{c}0.016 \\
(0.012)\end{array}$ & $\begin{array}{c}0.044 \\
(0.033)\end{array}$ & $\begin{array}{c}0.052 \\
(0.036)\end{array}$ & $\begin{array}{c}0.051 \\
(0.038)\end{array}$ \\
\hline Coverage & & & & & $\begin{array}{c}0.013 \\
(0.012)\end{array}$ & $\begin{array}{c}-8.08 \mathrm{E}-05 \\
(9.8 \mathrm{E}-05)\end{array}$ & $\begin{array}{l}1.78 \mathrm{E}-04 \\
(1.7 \mathrm{E}-04)\end{array}$ & $\begin{array}{c}7.99 \mathrm{E}-05 \\
(0.001)\end{array}$ & $\begin{array}{c}1.06 \mathrm{E}-04 \\
(0.001)\end{array}$ \\
\hline Market to Book & $\begin{array}{c}-0.005^{*} \\
(0.003)\end{array}$ & $\begin{array}{c}-0.027 * * \\
(0.011)\end{array}$ & $\begin{array}{c}-0.025 * * \\
(0.010)\end{array}$ & $\begin{array}{c}-0.025^{* *} \\
(0.010)\end{array}$ & $\begin{array}{c}-0.007 * * \\
(0.003)\end{array}$ & $\begin{array}{l}-0.006 \\
(0.004)\end{array}$ & $\begin{array}{c}-0.037 * * * \\
(0.014)\end{array}$ & $\begin{array}{c}-0.034 * * \\
(0.015)\end{array}$ & $\begin{array}{c}-0.034 * * \\
(0.016)\end{array}$ \\
\hline Log (Total Assets) & $\begin{array}{c}0.372 \\
(0.273)\end{array}$ & $\begin{array}{c}0.501 \\
(0.351)\end{array}$ & $\begin{array}{c}0.593 \\
(0.392)\end{array}$ & $\begin{array}{c}0.568 \\
(0.394)\end{array}$ & $\begin{array}{c}0.226 \\
(0.289)\end{array}$ & $\begin{array}{c}0.217 \\
(0.301)\end{array}$ & $\begin{array}{c}-0.295 \\
(0.536)\end{array}$ & $\begin{array}{l}-0.211 \\
(0.539)\end{array}$ & $\begin{array}{l}-0.114 \\
(0.494)\end{array}$ \\
\hline Rating & & & & & & & & & \\
\hline Investment Grade Rating & $\begin{array}{l}-0.778 \\
(0.498)\end{array}$ & $\begin{array}{l}-1.159 \\
(0.930)\end{array}$ & $\begin{array}{l}-1.243 \\
(0.955)\end{array}$ & $\begin{array}{l}-1.219 \\
(0.966)\end{array}$ & $\begin{array}{c}-1.724^{*} \\
(0.880)\end{array}$ & $\begin{array}{l}-0.493 \\
(0.596)\end{array}$ & $\begin{array}{l}-1.003 \\
(0.868)\end{array}$ & $\begin{array}{l}-1.542 \\
(1.134)\end{array}$ & $\begin{array}{l}-1.442 \\
(1.156)\end{array}$ \\
\hline Not Rated & $\begin{array}{l}-0.629 \\
(0.397)\end{array}$ & $\begin{array}{c}-3.648 * * * \\
(1.120)\end{array}$ & $\begin{array}{c}-3.433 * * * \\
(1.092)\end{array}$ & $\begin{array}{c}-3.486^{* * *} \\
(1.115)\end{array}$ & $\begin{array}{l}-0.540 \\
(0.509)\end{array}$ & $\begin{array}{c}-0.750^{*} \\
(0.404)\end{array}$ & & & \\
\hline Constant & $\begin{array}{c}-10.007 * * * \\
(2.186)\end{array}$ & $\begin{array}{c}-5.484^{*} \\
(2.928)\end{array}$ & $\begin{array}{c}-7.712 * * \\
(3.382)\end{array}$ & $\begin{array}{c}-8.036^{* * *} \\
(3.363)\end{array}$ & $\begin{array}{c}-8.142 * * * \\
(2.706)\end{array}$ & $\begin{array}{c}-10.458 \text { *** } \\
(2.506)\end{array}$ & $\begin{array}{c}-25.025 * * * \\
(8.856)\end{array}$ & $\begin{array}{c}-27.209 * * * \\
(8.616)\end{array}$ & $\begin{array}{c}-31.646 * * * \\
(10.262)\end{array}$ \\
\hline Year Fixed Effects & YES & YES & YES & YES & YES & YES & YES & YES & YES \\
\hline Industry Fixed Effects & YES & YES & YES & YES & YES & YES & YES & YES & YES \\
\hline Number of Observations & 4062 & 1633 & 1618 & 1618 & 3919 & 5273 & 707 & 691 & 679 \\
\hline $\mathrm{R}^{2}$ & 0.259 & 0.407 & 0.414 & 0.416 & 0.279 & 0.291 & 0.391 & 0.416 & 0.423 \\
\hline
\end{tabular}




\section{Appendix I}

SECTION 7.10. Certain Financial Covenants.

(a) Debt Ratio. The Borrower will not permit the Debt Ratio to exceed the following respective ratios at any time during the following respective periods:

Period

From the date hereof

through August 31, 2000

From September 1, 2000

through August 31, 2001

From September 1, 2001

and at all times thereafter
Ratio

4.75 to 1

4.50 to 1

4.25 to 1

4.00 to 1

(b) Senior Debt Ratio. The Borrower will not permit the Senior Debt Ratio to exceed the following respective ratios at any time during the following respective periods:

Period

From the date hereof

through February 29, 2000

From March 1, 2000

through August 31, 2000

From September 1, 2000

and at all times thereafter
Ratio

3.75 to 1

3.50 to 1

3.00 to 1

2.50 to 1

(c) Interest Coverage Ratio. The Borrower will not permit the Interest Coverage Ratio to be less than the following respective ratios at any time during the following respective periods:

Period

Ratio

From the date hereof

through August 31, 2000

From September 1, 2000

through August 31, 2001

From September 1, 2001

and at all times thereafter
2.25 to 1

2.00 to 1

1.75 to 1

1.50 to 1

(d) Fixed-charges Ratio. The Borrower will not permit the Fixed-charges Ratio to be less than 1.00 to 1 as at the last day of any fiscal quarter of each fiscal year. 